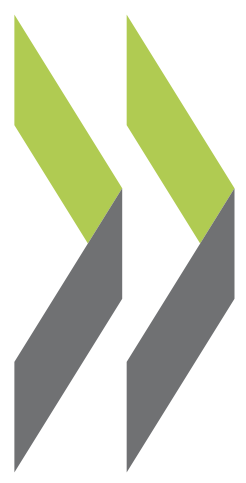

OECD Economics Department Working Papers No. 1479

\title{
Strengthening innovation \\ in Poland
}

\section{Nicola Brandt}

https://dx.doi.org/10.1787/abf2c877-en 
Organisation de Coopération et de Développement Économiques

Organisation for Economic Co-operation and Development

26-Jun-2018

ECONOMICS DEPARTMENT

English - Or. English

\section{STRENGTHENING INNOVATION IN POLAND}

ECONOMIC DEPARTMENT WORKING PAPERS No. 1479

\section{By Nicola Brandt}

OECD Working Papers should not be reported as representing the official views of the OECD or of its member countries. The opinion expressed and arguments employed are those of the author(s).

Authorised for publication by Álvaro Pereira, Acting Chief Economist, Economics Department.

All Economics Department Working Papers are available at www.oecd.org/eco/workingpapers

JT03434115

This document, as well as any data and map included herein, are without prejudice to the status of or sovereignty over any territory, to the delimitation of international frontiers and boundaries and to the name of any territory, city or area. 
OECD Working Papers should not be reported as representing the official views of the OECD or of its member countries. The opinions expressed and arguments employed are those of the author.

Working Papers describe preliminary results or research in progress by the author(s) and are published to stimulate discussion on a broad range of issues on which the OECD works.

Comments on Working Papers are welcomed, and may be sent to OECD Economics Department, 2 rue André Pascal, 75775 Paris Cedex 16, France, or by e-mail to eco.contact@ oecd.org.

All Economics Department Working Papers are available at www.oecd.org/eco/workingpapers.

This document and any map included herein are without prejudice to the status of or sovereignty over any territory, to the delimitation of international frontiers and boundaries and to the name of any territory, city or area.

The statistical data for Israel are supplied by and under the responsibility of the relevant Israeli authorities. The use of such data by the OECD is without prejudice to the status of the Golan Heights, East Jerusalem and Israeli settlements in the West Bank under the terms of international law.

On 3 May 2018, the OECD Council invited Lithuania to become a Member. At the time of publication the deposit of Lithuania's instrument of accession to the OECD Convention was pending and therefore Lithuania does not appear in the list of OECD Members and is not included in the OECD zone aggregates.

On 25 May 2018, the OECD Council invited Colombia to become a Member. At the time of publication the deposit of Colombia's instrument of accession to the OECD Convention was pending and therefore Colombia does not appear in the list of OECD Members and is not included in the OECD zone aggregates.

(C) OECD (2018)

You can copy, download or print OECD content for your own use, and you can include excerpts from OECD publications, databases and multimedia products in your own documents, presentations, blogs, websites and teaching materials, provided that suitable acknowledgment of OECD as source and copyright owner is given. All requests for commercial use and translation rights should be submitted to rights@oecd.org 
ECO/WKP(2018)27

\section{ABSTRACT/RÉSUMÉ}

\section{Strengthening innovation in Poland}

Poland's catch up with other OECD country has been largely based on productivity growth resulting from restructuring towards more productive sectors and foreign technology absorption. The economy's own innovation capacity is relatively weak, with low investment in research and development, no tradition of commercialising research and very limited innovation activity within firms. The government plans a higher education reform to strengthen the quality of research output, science-industry cooperation and international collaboration, which are all weak. Considerable EU funding is available to support innovation. Most of it is conditioned on science-industry co-operation, which is showing initial benefits. A lively start-up scene is gradually emerging, and the government foresees considerable public support for venture capital financing. Yet, investment in higher education and research trails behind economies that have been able to build strong science and high-tech start-up activity. Poland's many small and mediumsized enterprises have particularly low productivity, partly related to weaknesses in vocational training and adult education, as too many workers have weak basic and digital skills. The government's education reform and digital strategy address some of these issues.

This Working Paper relates to the 2018 OECD Economic Survey of Poland (www.oecd.org/eco/surveys/economic-survey-poland.htm).

JEL: O31; O32; O4; I23

Keywords: Poland, innovation, research and development, higher education, vocational education

$* * * * * * * *$

\section{Renforcer l'innovation en Pologne}

Le rattrapage de la Pologne par rapport à d'autres pays de l'OCDE a été largement fondé sur la croissance de la productivité résultant de la restructuration vers des secteurs plus productifs et de l'absorption de technologies étrangères. La capacité d'innovation de l'économie polonaise est relativement faible, avec peu d'investissements dans la recherche et le développement, l'absence d'une tradition de commercialisation de la recherche et une activité d'innovation très limitée au sein des entreprises. Le gouvernement prévoit une réforme de l'enseignement supérieur pour renforcer la qualité des résultats de la recherche, la coopération entre le monde scientifique et les entreprises ainsi que- la collaboration internationale, qui sont toutes faibles. La Pologne dispose d'un financement de l'UE considérable pour soutenir l'innovation, mais souvent uniquement à condition d'une coopération entre le monde scientifique et les entreprises, ce qui montre des premiers résultats. Une scène dynamique de start-ups émerge progressivement, et le gouvernement prévoit un soutien public considérable pour le financement du capital-risque. Pourtant, les investissements dans l'enseignement supérieur et la recherche sont plus faibles que dans des économies qui ont été en mesure d'établir de la recherché de haute qualité et une forte activité de start-ups liée aux hautes technologies. Les nombreuses petites et moyennes entreprises polonaises ont une productivité particulièrement faible, en partie à cause des faiblesses de la formation professionnelle et de l'éducation des adultes, car trop de travailleurs ont de faibles compétences de base et numériques. La réforme de l'éducation et la stratégie numérique du gouvernement répondent à certaines de ces questions.

Ce Document de travail se rapporte à l'Étude économique de l'OCDE de la Pologne 2018

(http://www.oecd.org/fr/economie/etude-economique-pologne.htm)

JEL: O31; O32; O4; I23

Keywords: Pologne, innovation, recherche et développement, enseignement supérieur, formation professionnelle 


\section{TABLE OF CONTENTS}

\section{STRENGTHENING INNOVATION IN POLAND 6}

Introduction $\quad 6$

$\begin{array}{ll}\text { Poland's capacity to innovate needs to be strengthened } & 7\end{array}$

Productivity growth has slowed down $\quad 7$

Innovation investment, output and demand are weak 9

The innovation system has been streamlined and coordination improved 12

Strengthening the quality of higher education and research 14

The importance of research and the supply of graduates for innovation $\quad 14$

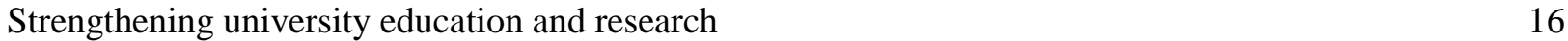

$\begin{array}{ll}\text { Commercialisation of research results } & 20\end{array}$

$\begin{array}{ll}\text { Developing enterprise and innovative activity } & 21\end{array}$

$\begin{array}{ll}\text { Stimulating innovative start-ups } & 21\end{array}$

Promoting firm entry, growth and innovation through regulatory reform $\quad 23$

Agglomerations with strong firm networks, training and coaching services support innovation 25

$\begin{array}{ll}\text { Adult learning and vocational training } & 28\end{array}$

Strengthening demand for innovation through public procurement 33

BIBLIOGRAPHY 38

\section{Tables}

1. Poland's research and innovation system 13

\section{Figures}

1. Poland's per capita income is converging, but a challenging demographic decline lies ahead 6

2. Productivity growth has been strong, with industrial restructuring as a key factor 7

3. The employment share in more innovative industries is relatively weak $\quad 8$

4. Labour productivity is relatively low, particularly among microenterprises $\quad 8$

5. Spending on innovation is low and mainly aimed at existing technologies 9

6. The gap in $R \& D$ intensity with more advanced economies is pervasive 10

7. Stock of inward FDIs in R\&D-intensive industries 11

8. Patents counts and trademark applications are low 12

9. Quality in tertiary education has improved, but some weaknesses persist 15

10. Research output is relatively weak and poorly integrated within international research networks 16

11. The supply of researchers is weak, $2015 \quad 17$

12. Spending on tertiary education should be increased further, $2014 \quad 18$

13. The quality of management is relatively low in domestic firms 22

14. Setting up a business and paying taxes remain onerous 24

15. The Łódź special economic zone has performed particularly strongly, 2005-15 27 
16. Lifelong learning is underdeveloped, especially for low-skilled and senior individuals

17. The skills of students and graduates from basic vocational schools are weak, 2012

18. Low skills are pervasive and weigh on labour market outcomes, 2012

19. Demand for innovation is low, 2016-17

20. ICT penetration is low, 2016

\section{Boxes}

Box 1. A tale of two high-tech inventions

Box 2. Aligning education better with business needs - examples from the Łódź region

Box 3. Firms addressing skill gaps by sponsoring dual vocational education programmes

Box 4. Innovation through public procurement in Poland

Recommendations to strengthen innovative capacity in Poland 


\title{
STRENGTHENING INNOVATION IN POLAND
}

\author{
By Nicola Brandt ${ }^{1}$
}

\section{Introduction}

Poland is experiencing robust economic growth, and the catch-up with average living standards in OECD countries over the past 25 years has been impressive (Figure 1, Panel A). However, strong economic performance has been largely based on the production and export of relatively low-technology goods. GDP per capita still stood around 30\% below the EU28 average in 2016. The working-age population is falling, and a recent decision to lower the retirement age will exacerbate the resulting pressure on the labour force (Panel B). Strong productivity gains are therefore needed to sustain increases in living standards.

Figure 1. Poland's per capita income is converging, but a challenging demographic decline lies ahead

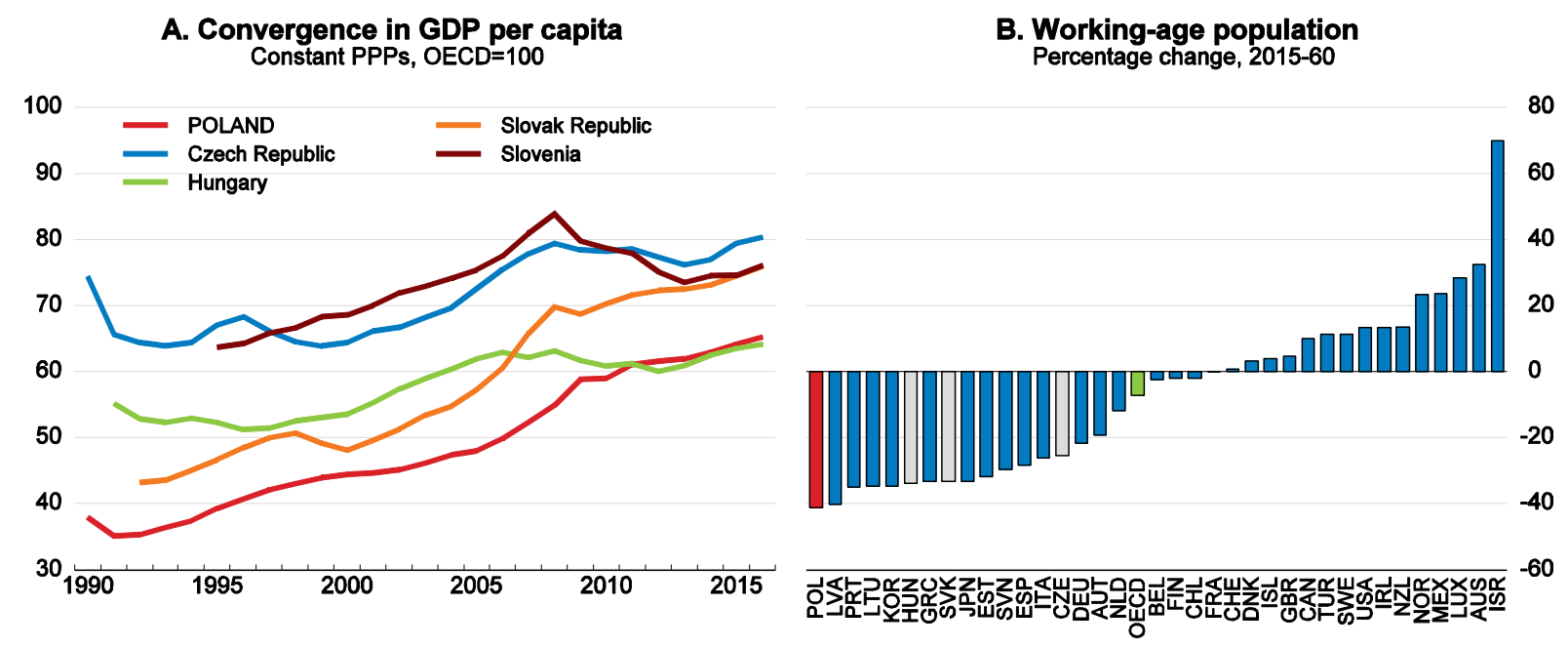

Source: OECD (2017), OECD National Accounts Statistics (database); United Nations (2017), "World Population Prospects: The 2017 Revision", Department of Economic and Social Affairs, United Nations, New York.

Over the past 25 years, productivity gains were achieved mainly by moving workers from agriculture to more productive sectors and by adopting foreign technologies. To strengthen productivity gains Poland now needs to invest more in its own capacity to innovate, allowing firms to modernise their organisation and production procedures, adopt new technologies and products and adapt them to the local market. This will require investment in higher education and research along with efforts to strengthen weak industryscience cooperation, but also engagement of higher education institutions with the wider society. Highquality science will be essential to lift currently low business research and development (R\&D) spending and promote the creation and growth of more innovative enterprises. Enhanced basic-skills training and more business engagement in vocational education is also needed, as it would allow Poland's numerous low-productivity micro-enterprises to improve their performance.

This paper has been authored by Nicola Brandt from the OECD. The paper benefitted greatly from comments and suggestions from Peter Jarrett, Pierre Guérin, Antoine Goujard, Balázs Egert, Iga Magda, Claudia Sarrico, Agnieszka Chłon-Domińczak, Krzysztof Klincewicz and Joanna Tyrowicz. I thank Patricio Sicari for excellent research assistance and Sylvie Ricordeau for excellent secretarial assistance. 
This paper is organised as follows. The next section discusses Poland's innovation system, productivity and innovation outcomes. Thereafter, policies to strengthen higher education, research and its commercialisation are discussed. The final section reviews policies to strengthen entrepreneurship, ranging from foreign direct investment over high-tech start-up activity to policies promoting productivity in more mature small and medium enterprises (SMEs), notably through vocational education and training.

\section{Poland's capacity to innovate needs to be strengthened}

\section{Productivity growth has slowed down}

As in other central and Eastern European countries (CEECs), total factor productivity has grown more rapidly than in other OECD economies since 2000. Yet, there has been a slowdown that started before the 2008 financial crisis (Figure 2, Panels A and B). Flows of labour and capital from low-productivity sectors, mainly agriculture, to higher-productivity market services and industrial sectors has contributed to aggregate productivity growth (Panels $\mathrm{C}$ and $\mathrm{D}$ ). A favourable tax and social security regime for the agricultural sector continues to retain too many workers in small, low-productivity farms, while the employment share in high-tech sectors and ICT-intensive industries remains relatively low (Figure 3, Panel A and B). So there is still potential to shift labour and capital to more productive activities. Yet, to strengthen productivity growth in the long term, allowing for higher living standards, efforts to improve efficiency within companies and sectors are needed, as well.

Figure 2. Productivity growth has been strong, with industrial restructuring as a key factor

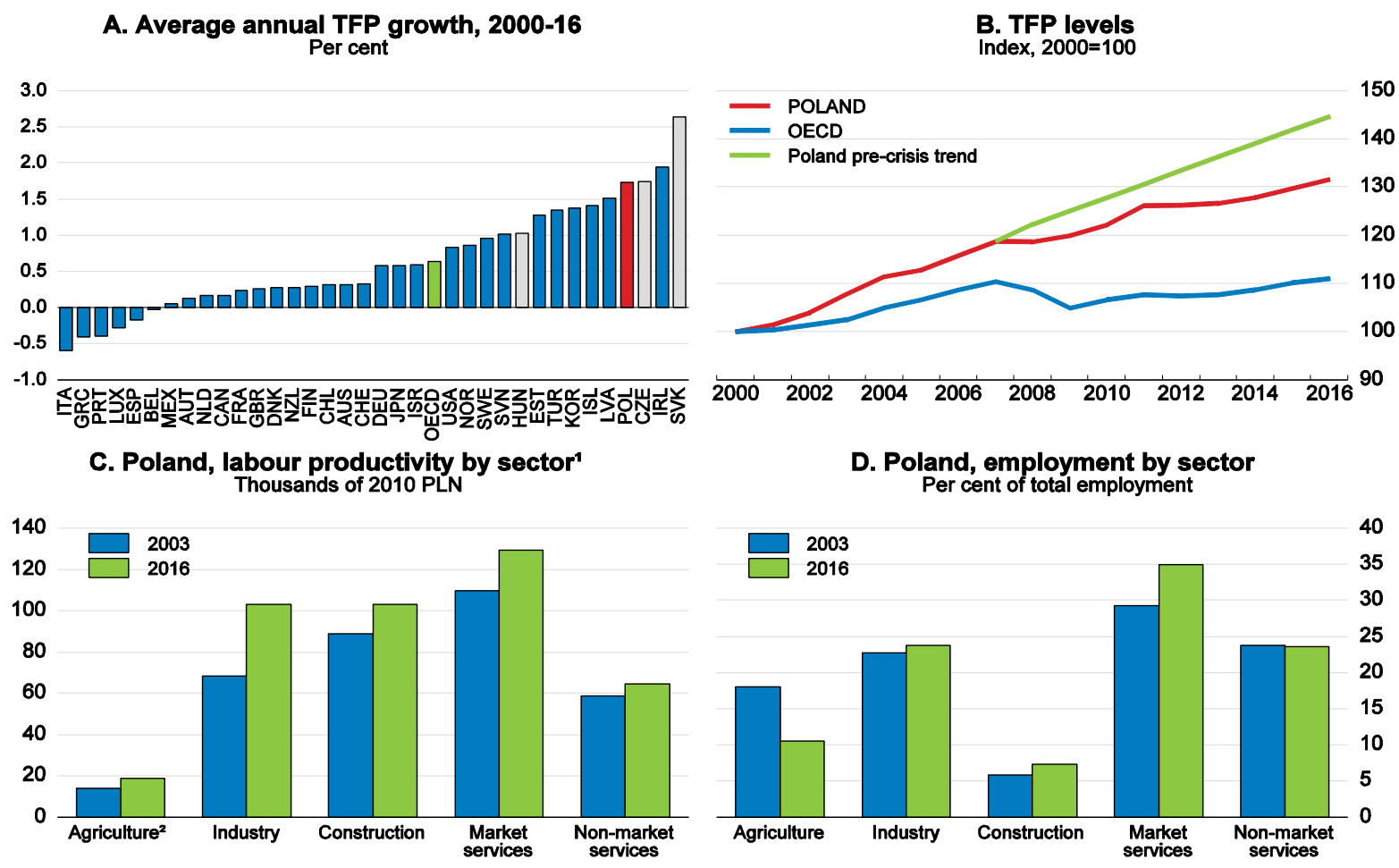

1. Labour productivity is defined as value added per worker.

2. Latest observation refers to 2015 .

Source: OECD (2017), Economic Outlook: Statistics and Projections and OECD National Accounts Statistics (databases). 
Figure 3. The employment share in more innovative industries is relatively weak

\section{A. Share of employment in high and medium-high R\&D-intensive sectors ${ }^{1}$ \\ Per cent of total employment ${ }^{2}, 2016^{3}$}

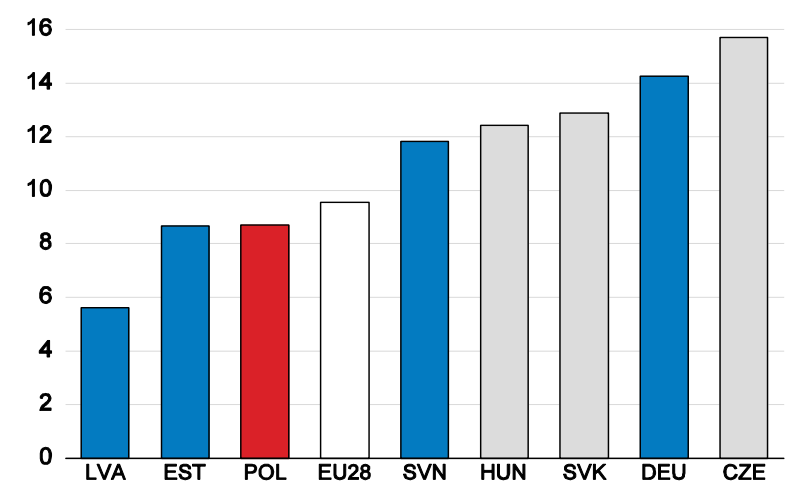

B. Share of employment in ICT-intensive sectors 4

Per cent of total employment, $2016^{3}$

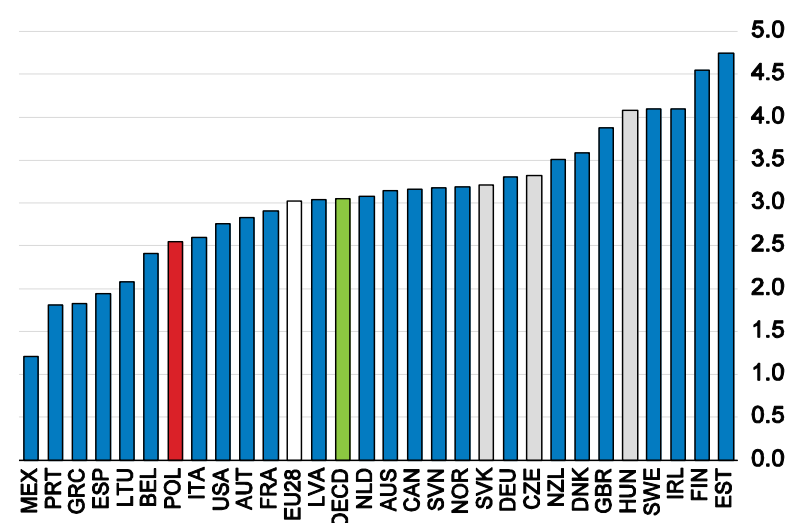

1. R\&D intensity is measured as the ratio of ISIC Rev.4 industries' intramural R\&D expenditure to industries' gross value added; high and medium-high R\&D-intensive sectors are identified based on the taxonomy proposed in $\mathrm{F}$. Galindo-Rueda and $\mathrm{F}$. Verger (2016), "OECD Taxonomy of Economic Activities Based on R\&D Intensity", OECD Science, Technology and Industry Working Papers, 2016/04, OECD Publishing, Paris.

2. Excluding public administration, defence and compulsory social security, education, human health and social work activities.

3. Or most recent year available.

4. The ICT-intensive sector is defined as the sum of ISIC Rev.4 industries 26, 58, 61 and 62-63.

Source: OECD (2017), OECD Research and Development Statistics and National Accounts Statistics (databases).

The productivity gap with other OECD countries is considerable, particularly so for the smallest enterprises (Figure 4, Panel A). Only in manufacturing is there some catching up with larger firms whose productivity growth has been relatively slow (Panel B and C). Enterprises with less than 10 employees make up 95\% of all firms in Poland and employ more than a third of all workers. Boosting their efficiency and promoting their growth is key to strengthening the economy overall.

Figure 4. Labour productivity is relatively low, particularly among microenterprises

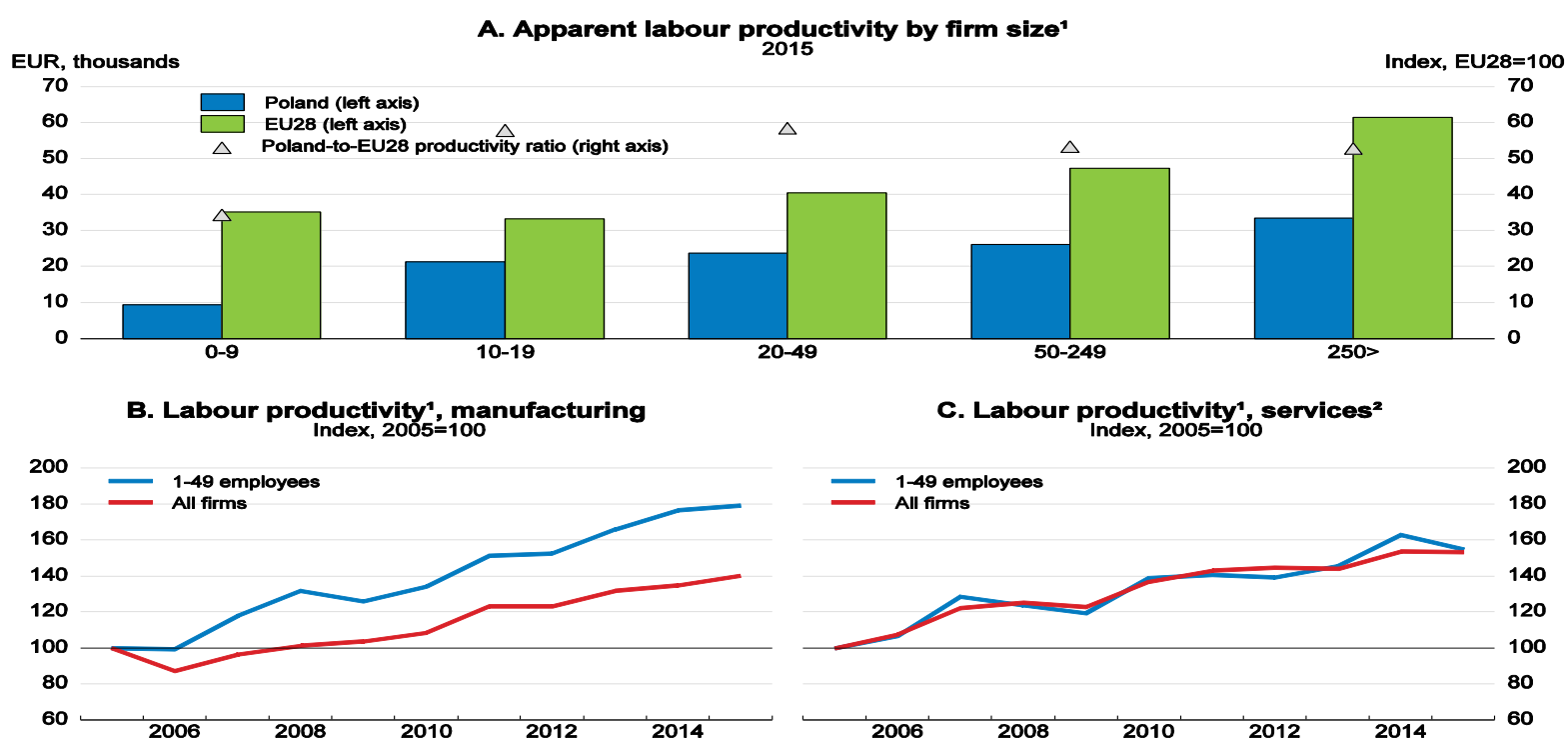

1. Gross value added per person employed.

2. Refers to 2-digit items from 45 to 82 of the ISIC-Rev. 4 classification.

Source: Eurostat (2017), "Annual enterprise statistics by size class for special aggregates of activities", Eurostat Database; OECD (2017), OECD Structural and Demographic Business Statistics - SDBA (database). 


\section{Innovation investment, output and demand are weak}

In line with Poland's position as a technology follower spending on innovation has been dominated by investment in existing technologies rather than genuine inventions. The share of innovation expenditure for acquiring existing machinery, equipment or software is high, although even here the level is relatively low. Investment in R\&D overall remains relatively low in relation to GDP, but business R\&D has increased rapidly lately. The share of innovative firms is comparatively low, and unlike in other CEECs, this also holds for the largest firms (Figure 5).

\section{Figure 5. Spending on innovation is low and mainly aimed at existing technologies}

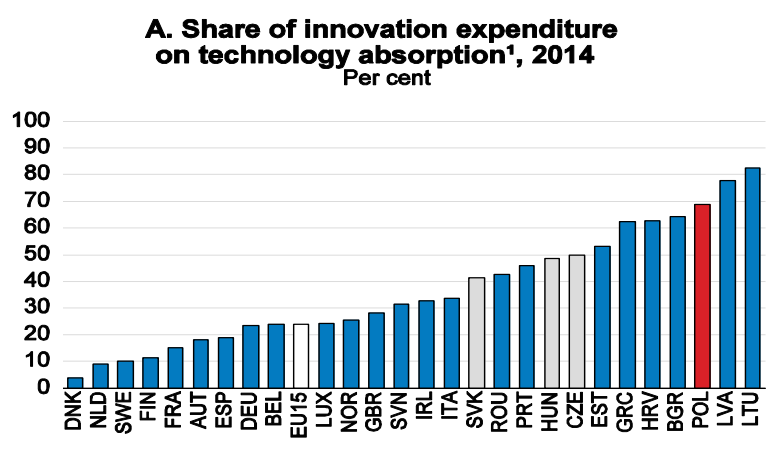

C. Business expendlture on R\&D, 2005-15 Average annual growth rates, per cent, constant USD PPPs

16

12

8

4

0

$-4$

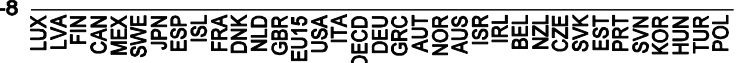

B. Gross domestic expenditure on R\&D, $2015^{2}$
Per cent of GDP

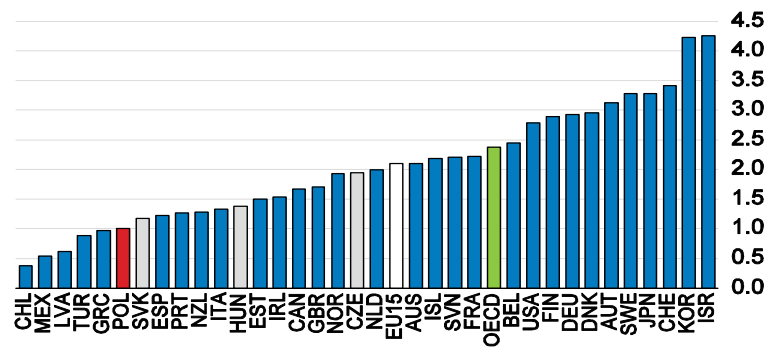

D. Share of Innovative flrms ${ }^{3}, 2014$

Per cent of all firms

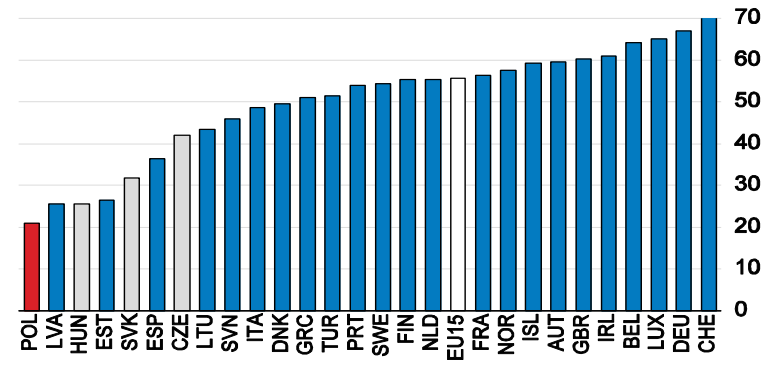

1. Share of machinery, equipment and software acquisition in total innovation expenditure.

2. Or latest year available.

3. Firms having implemented a new or significantly improved product (good or service), process, new marketing or organisational method in business practices, workplace organisation or external relations.

4. Excluding agriculture and non-market services.

Source: Eurostat (2016), “Community Innovation Survey (CIS) 2014”, Eurostat Database; OECD (2017), Research and Development Statistics (database).

Low business R\&D spending is pervasive. Poland specialises in sectors where firms tend to do relatively little R\&D. The value added shares of construction, trade and the food and beverages industries, where R\&D investment is low, are significantly higher than in other European countries. In turn, the value added share in most manufacturing industries with high $R \& D$ intensity is relatively low. But sectorspecific R\&D intensities are also comparatively low, both in high- and in low-tech industries (Figure 6). 
Figure 6. The gap in R\&D intensity with more advanced economies is pervasive ${ }^{1}$

Top 10 most R\&D-intensive industries ${ }^{2}$ in EU1033, average 2010-13

\section{A. Difference in the shares of industries' total value added EU10 $0^{3}$ v. Poland, percentage points}

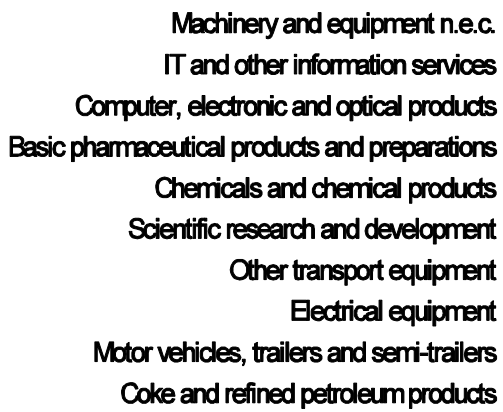

Machinery and equipment n.e.c.

$\Pi$ and other information services

Computer, electronic and optical products Basic pharmaceutical products and preparations

Chemicals and chemical products

Scientific research and development

Other transport equipment

Eectrical equipment

Motor vehicles, trailers and semi-trailers

Coke and refined petroleum products

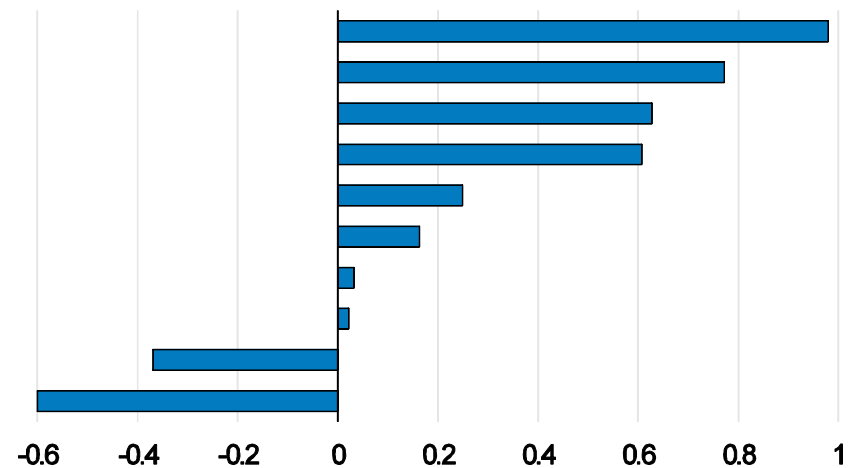

1.2

\section{B. R\&D intensity comparison}

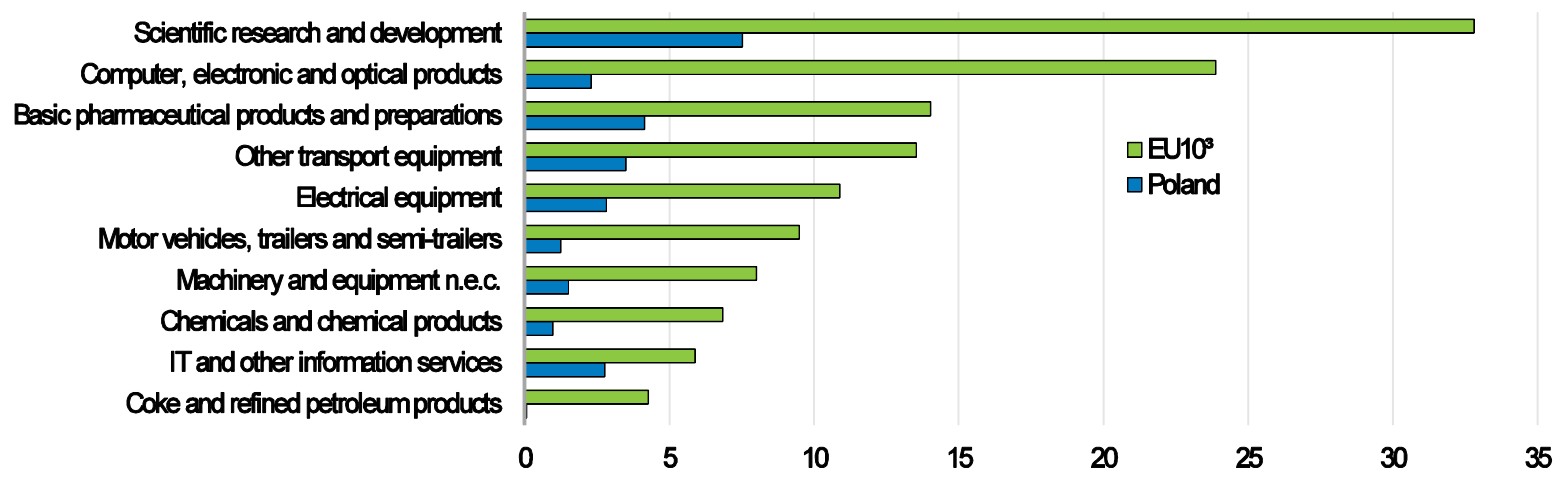

1. R\&D intensity by industry is defined as the ratio of industry's $R \& D$ expenditure to the industry's gross value added.

2. Divisions of the ISIC-Rev. 4 classification.

3. EU10 refers to the simple average of sectoral shares across Austria, Belgium, Denmark, Finland, France, Germany, Italy, the Netherlands, Spain and Sweden.

Source: OECD (2017), OECD Research and Development Statistics and National Accounts Statistics (databases).

Foreign companies contribute less to R\&D-spending than in neighbouring countries. Foreign direct investment is reasonably high in R\&D-intensive sectors, but less so than in a number of neighbouring countries with similar GDP per capita. In the R\&D sector itself it is relatively low. Overall, R\&D spending by the affiliates of foreign companies in manufacturing remains comparatively low, although it has been increasing (Figure 7). 
Figure 7. Stock of inward FDls in R\&D-intensive industries
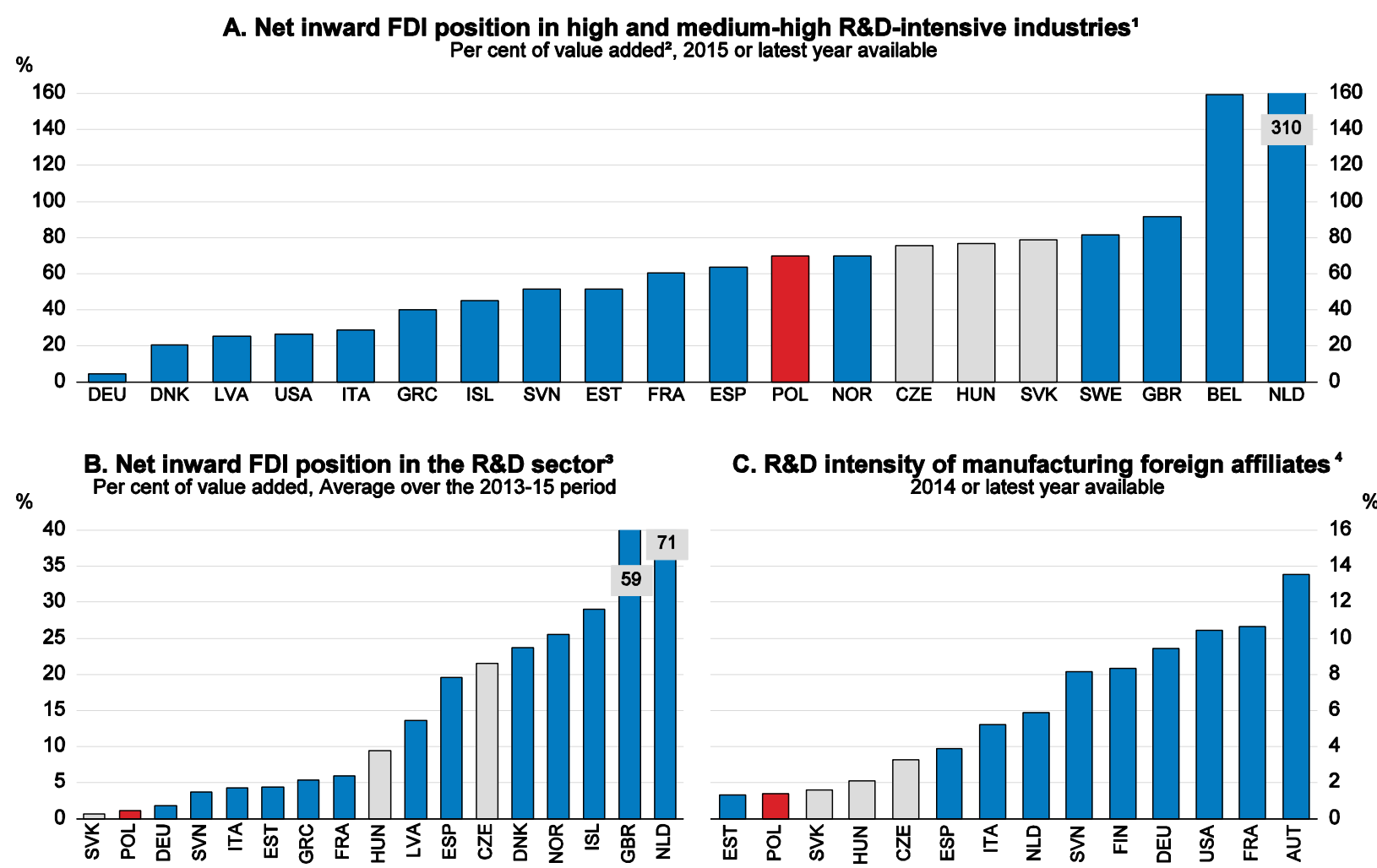

1. High and medium-high R\&D intensive sectors do not include electrical equipment (division 27 of ISIC's Rev 4 classification), for which data on net inward FDI positions are not available.

2. For Czech Republic and the Netherlands, industry coverage excludes pharmaceuticals (21); net inward FDI positions exclude those in chemicals and pharmaceuticals $(20,21)$ for Norway and Sweden, with the latter also excluding scientific research and development (72); data for the United States are based on manufacturing activities, excluding scientific R\&D, publishing activities and IT services $(72,58,62-63)$.

3. Division 72 of ISIC's Rev 4 classification, i.e. scientific research and development.

4. R\&D intensity is defined as foreign affiliates' intramural R\&D spending as a percentage of their gross value added.

Source: OECD (2017), OECD FDI Statistics; OECD National Accounts Statistics and OECD Activity of Multinational Enterprises AMNE (databases).

Innovation output is weak. This is evidenced by the paucity of patent applications. The number of trademark applications abroad is also low (Figure 8). The share of Polish patents owned by foreign residents is relatively high, although less so than in some neighbouring countries. 
Figure 8. Patents counts and trademark applications are low

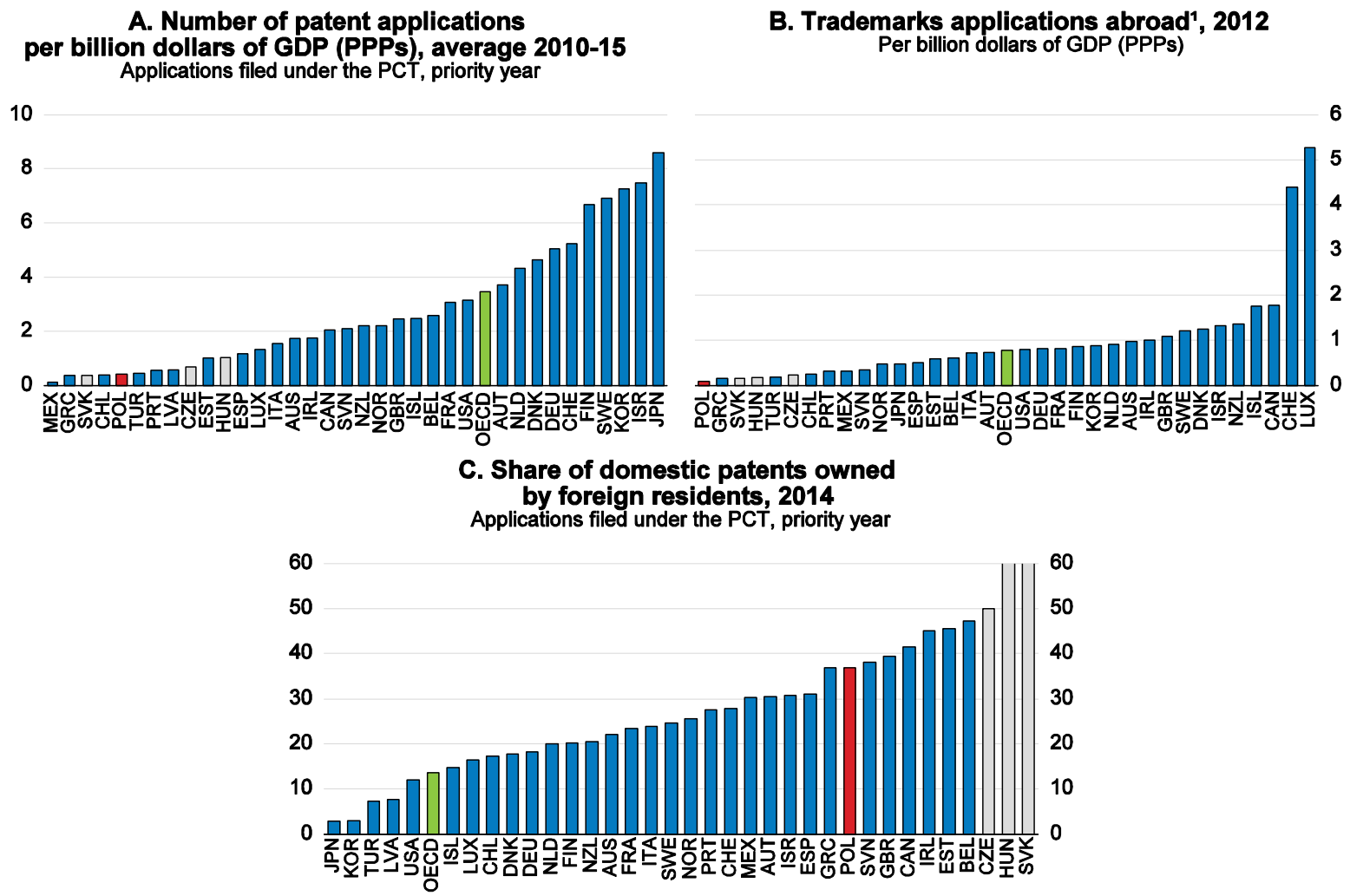

1. Trademarks abroad correspond to the number of applications filed at the USPTO, the OHIM and the JPO, by application date and country of residence of the applicant.

Source: OECD (2017), OECD Patent Statistics (database); OECD (2016), Science, Technology and Industry Outlook (database).

\section{The innovation system has been streamlined and coordination improved}

Poland has moved to better coordinate its innovation policies, which should help improve efficiency. The bulk of support for innovation, entrepreneurship and SMEs is financed by EU funds; around 20 billion euros are foreseen in the 2014-20 financing period for regional and central government programmes focussing mainly on stimulating innovation. In the past responsibility for innovation was spread across many different ministries and public agencies with little coordination (Kapil et al., 2013). But in 2016 the government created a Ministerial Council for Innovation, which meets regularly to coordinate innovation policy across ministries (see Table 1). The Polish Development Fund (Polski Fundusz Rozwoju, PFR) was remodelled in 2016 to become an umbrella organisation for the development bank (Bank Gospodarstwa Krajowego, BGK) and a number of government agencies responsible for SMEs (Polish Agency for Enterprise Development, PARP), export credits, investment promotion and industrial development. They now share a common logo and a single contact point. Their key innovation and investment support measures are bundled together in a few packages, each fit for a different stage of enterprise development. This should make it easier for firms to find support adapted to their needs, reduce administrative costs and enhance effectiveness. 
Table 1. Poland's research and innovation system

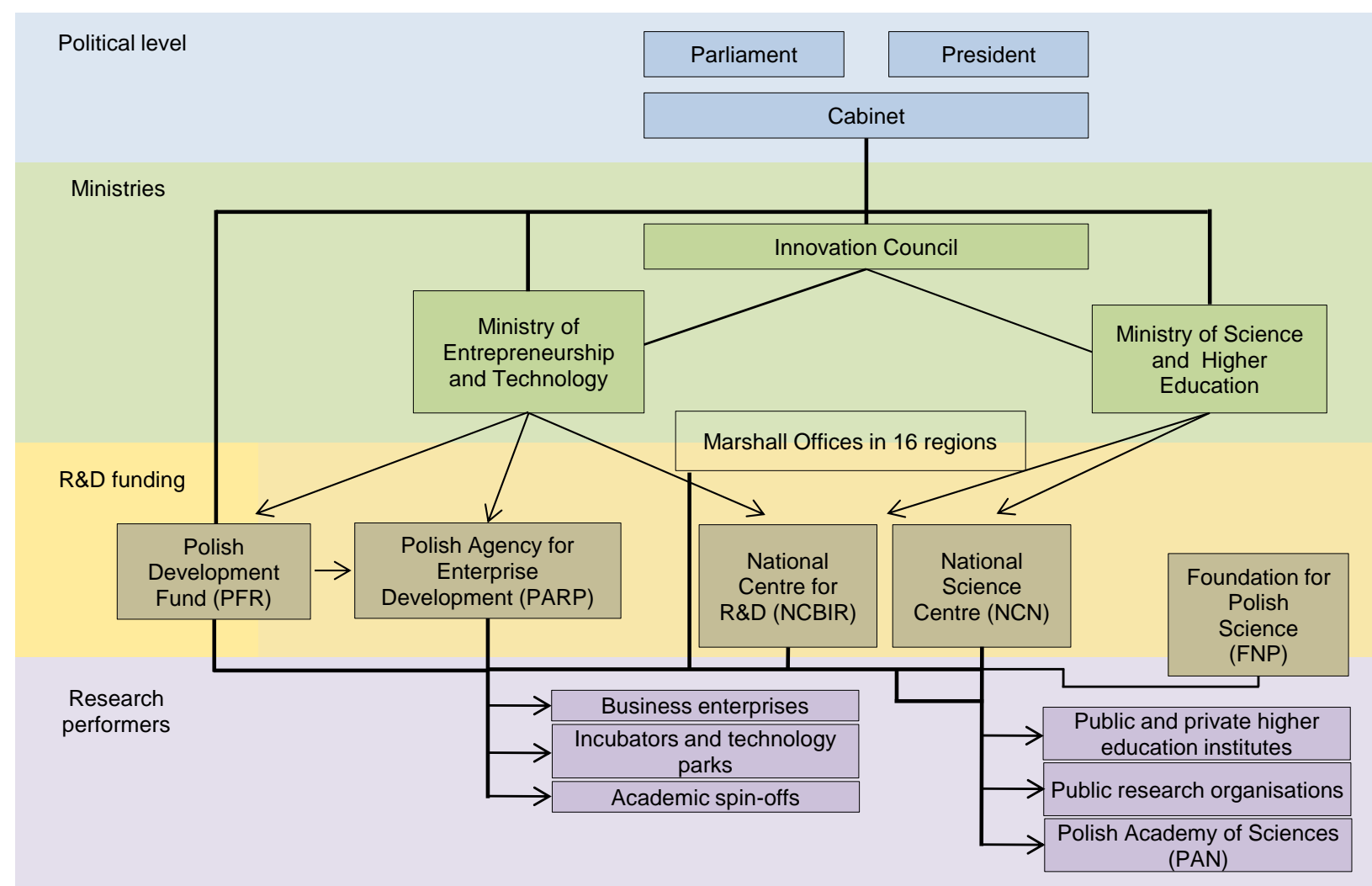

Source: K. Klincewicz and K. Szkuta (2015), RIO Country Report: Poland, Joint Research Centre, Sevilla.

There is now a clear assignment of responsibilities for research and development support. The National Science Centre (Narodowe Centrum Nauki, NCN) supports basic research, while the National Centre for Research and Development (Narodowy Centrum Badań i Rozwoju, NCBiR), specialises in applied research. Both are overseen by the Ministry of Higher Education and Research. The NCN mainly supports research at public Higher Education Institutions (HEIs) and the Polish Academy of Sciences (PAN), a large national institution with a focus on fundamental research. Private HEIs concentrate mostly on teaching, the majority in social sciences and humanities. NCBiR support goes largely to business enterprises or industry-science consortia and Public Research Organisations (PROs), which specialise in different areas of applied research, but also to universities. Many public HEIs have technology transfer offices and some have special purpose vehicles that act as holding companies for academic spin-offs to foster research commercialisation, and these can also receive support from the NCBiR. In recent years the government has used EU funds to set up clusters, business incubators and technology parks in an effort to support innovation through co-location of firms and sometimes research institutions (Table 1). The government also plans to set up a Foundation of the Industry of the Future to facilitate digitalisation and process innovation in the industrial sector.

Thanks to the EU smart specialisation strategy there now seems to be better coordination between the national and regional innovation policies and a closer dialogue with stakeholders. In the current EU financing period both the regions and the national government are required to focus EU-financed innovation support on so-called smart specialisations. These are areas where the economy is believed to have a comparative advantage or potentially strong innovation capacity. They were chosen in a so-called entrepreneurial discovery process involving intense consultations with enterprises and research institutions. The smart specialisation concept goes back to Foray (2013) building on work by Hausmann and Rodrik 
(2003) on industrial policies in Korea, Chinese Taipei and Japan. While national and regional innovation programmes were poorly coordinated in the past (Kapil et al., 2013), the selection, monitoring and evaluation of smart specialisations have involved regular consultations between the regions and the central government. The government is working with the regions to develop quantitative indicators to evaluate smart specialisations, there are monitoring committees comprising policy makers and stakeholders to review performance, and both the central government and some regions plan to set up an observatory to monitor and update the specialisations. The challenge is now to move from a list of targeted technologies to a learning process allowing for updates, should some of the chosen activities turn out not to have the anticipated potential. Government officials are enthusiastic about their experience with bringing together different enterprises, research and financing institutions often for the first time, as cooperation between industry and science and networking among enterprises is generally thought to be weak in Poland. They are hopeful that the process by itself could yield benefits through better information exchange, networking and cooperation.

Evaluation of innovation policies needs to be strengthened. In the past, many programmes have been evaluated ex post, often through external consultancies, and the government commissioned a review of its innovation programme under the previous EU financing period. With few exceptions it is qualitative and descriptive in nature rather than attempting to quantify economic effects of innovation support. There are now methodologically more sophisticated evaluations, but this needs to become more systematic. An inbuilt learning mechanism based on systematic evaluation of economic effects is needed to continuously improve the effectiveness of innovation policy. Systematically collecting hard indicators to evaluate effects is crucial, but an experimental design will often be necessary to identify these effects in a reliable way. For example, in oversubscribed clusters or technology parks places could be assigned through a lottery to later compare winners and losers. While this can be very costly, setting aside some money to ensure that programmes are continuously improved is worthwhile, given the amount of money involved. To provide financing for evaluation of programmes targeting youngsters the French government set up an "experimentation fund for youngsters". This can serve as an inspiration. Both PARP and evaluation units in ministries have the capacity to run and oversee complex evaluation. There are also good examples at NCBiR, which accompanies its programmes with evaluation of economic effects at regular intervals.

\section{Strengthening the quality of higher education and research}

\section{The importance of research and the supply of graduates for innovation}

Academic research excellence has been shown to stimulate the growth of local industrial R\&D and the set-up of new research intensive ventures in the region. As an example, Abramovsky et al. (2007) show that private-sector research labs in the United Kingdom locate close to highly rated university departments in chemicals and pharmaceuticals, with a stronger effect for foreign-owned labs, consistent with the notion that multinationals source technology globally. But there is also evidence of co-location with some lowerrated university departments, for example in machinery and communications, suggesting that more applied public research may also have a positive impact on private-sector research and business creation. Harhoff (1999) shows that high-technology firm entry is positively related to a large employment share of scientists in universities and extra-university research laboratories, in addition to the presence of business services and a diverse industry structure.

The location decisions of multinational research and development projects, as well, are driven by academic research excellence and agglomeration economies. Belderbos et al. (2014) find that high quality of relevant academic publications from universities in the region increases the likelihood of foreign R\&D investment, as does the supply of doctoral graduates. Siedschlag et al.'s (2013) results suggest that the probability of R\&D-intensive foreign firms locating in an EU region increases with local human capital, proximity to centres of research excellence, as well as business and government R\&D and patent intensity. 
The probability is also higher in regions where there is already intensive foreign $R \& D$ activity, pointing to agglomeration economies. Thus, promoting the excellence of local universities and research centres, along with encouraging the supply of science graduates is the best strategy to promote private $R \& D$, whether domestic or foreign.

Poland has experienced a tertiary education boom, but there is considerable potential to raise quality. The share of tertiary graduates has increased substantially and is now above the OECD average for younger age cohorts (Figure 9, Panel A). However, the share of young tertiary graduates with very weak literacy and numeracy skills at the border of illiteracy is sizeable (Panel B). Among adults there are few top performers in technology problem-solving (Panel C), although this looks a bit better in the younger generation (Panel D). The government has started to address quality issues in tertiary education by strengthening accreditation, but more needs to be done to improve the quality of teaching in general and the training of researchers in particular. The government supports the development of research human capital with EU Funds. Beyond that, better guidance services are needed to identify students with basicskills issues and refer them to education programmes that are better adapted to their abilities, such as vocational education with a strong focus on practical education and a basic-skills training component.

Figure 9. Quality in tertiary education has improved, but some weaknesses persist

\section{A. Share of tertiary-graduates in the 25-34 age group}

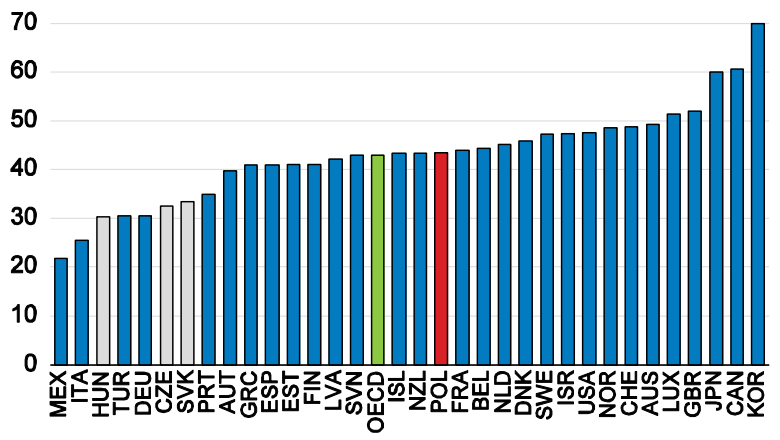

C. Share of top performers in problem-solving in technology-rich environments

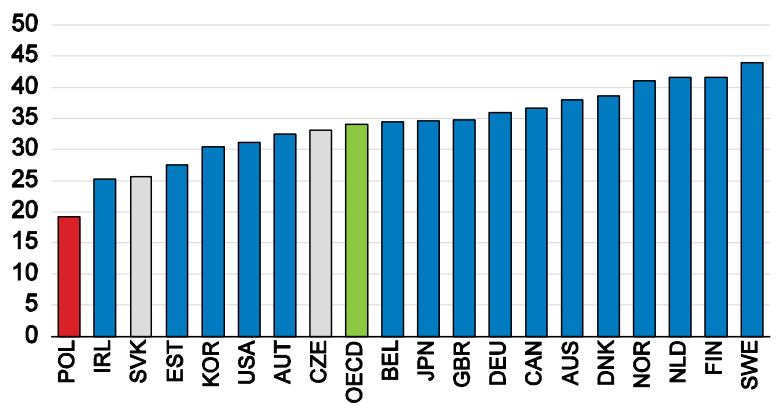

B. Young graduates with weak skills
Per cent of $20-34$ years old graduates, $2012^{2}$

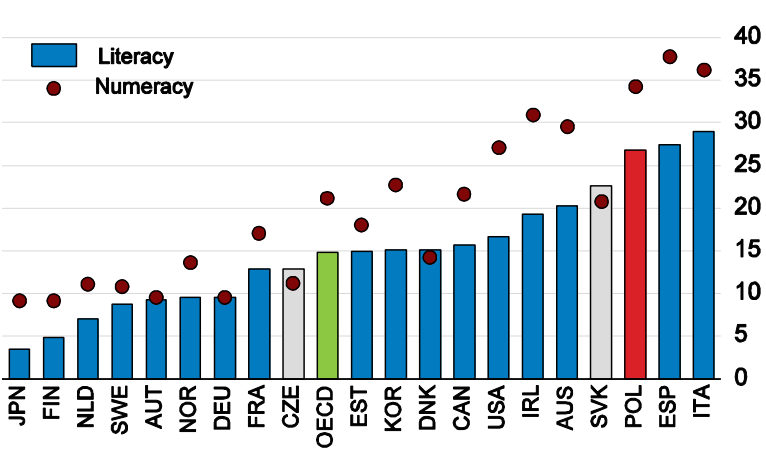

D. Share of 15 year-old students who are
top performers in science 2014

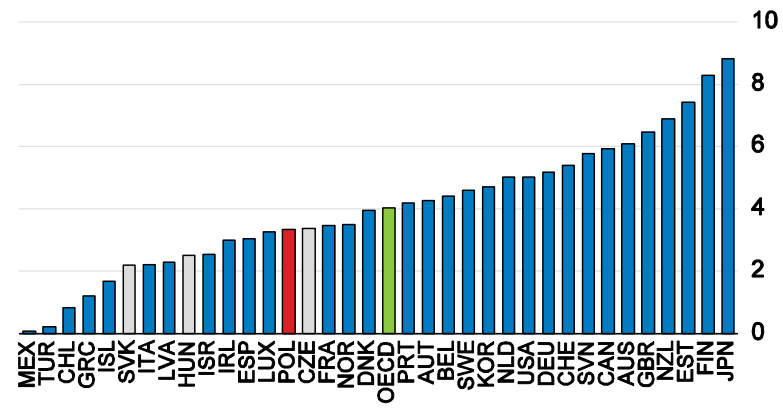

1. Share of adults scoring at or below level 1 of the PIAAC scale of literacy and numeracy proficiency.

2. The data are based solely on Flanders for Belgium, and England and Northern Ireland for the United Kingdom.

Source: OECD (2017), OECD Education at a Glance 2017 (database); OECD (2013), OECD Skills Outlook 2013 (database); OECD (2016), PISA 2015 Results: Excellence and Equity in Education, OECD Publishing, Paris.

Research output of Polish higher education and research institutions is well below the European average. Both the quantity and the quality of publications are comparatively low by bibliographic 
measures. International collaboration is weak, as is the cooperation of science with industry (Figure 10). Both need to be strengthened to improve the quality of research and opportunities to commercialise results.

Figure 10. Research output is relatively weak and poorly integrated within international research networks
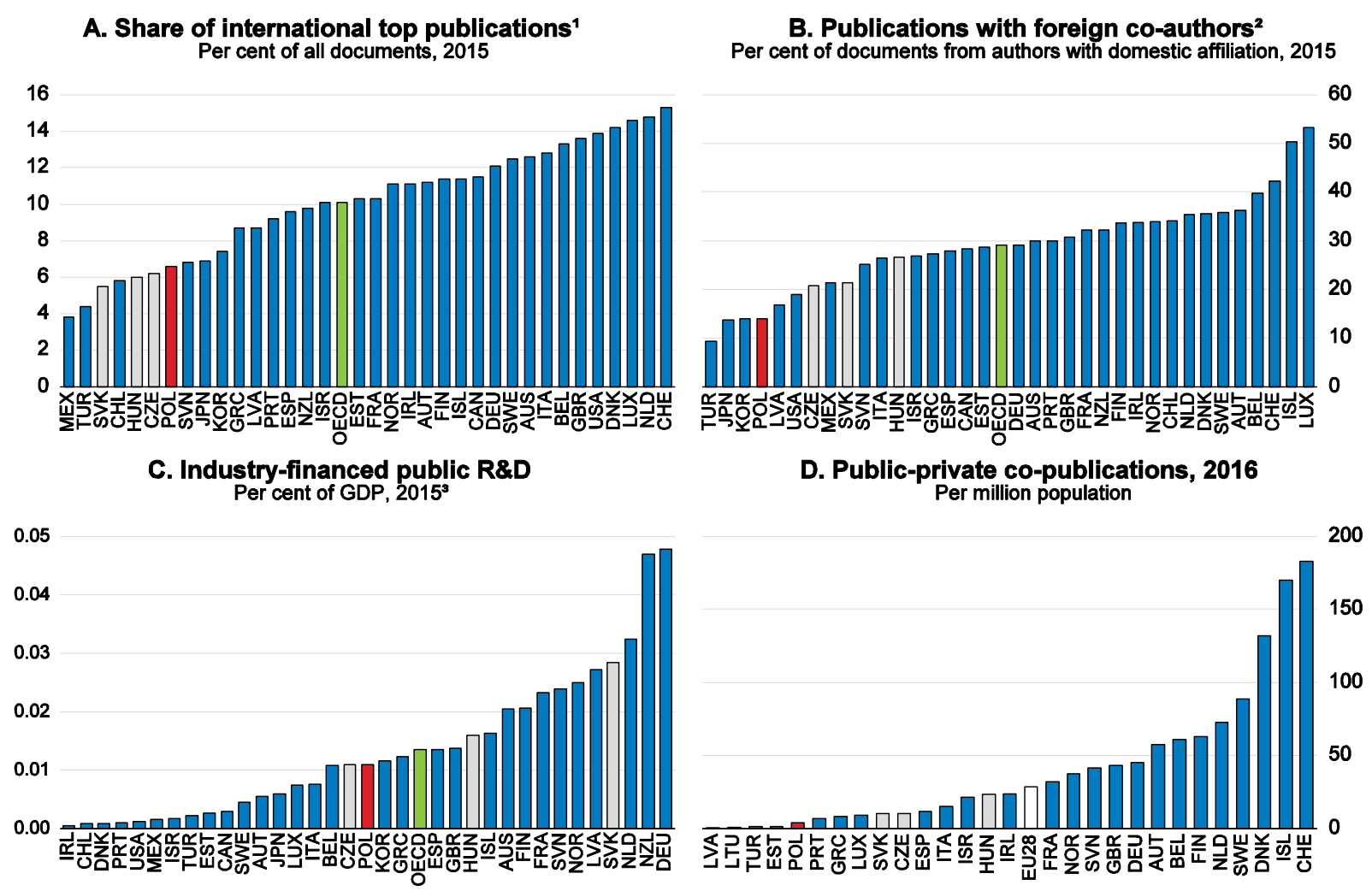

1. Share of the scientific output of domestic research institutions that is included in the set of the $10 \%$ most cited papers in their respective scientific fields, fractional counts.

2. Scientific documents involving institutional affiliations with research units of other countries as a percentage of scientific documents attributed to authors with a domestic affiliation, fractional counts.

3. Or latest year available.

Source: OECD (2017), OECD Science, Technology and Industry Scoreboard 2017, OECD Research and Development Statistics and OECD Economic Outlook: Statistics and Projections (databases); Eurostat (2017), European Innovation Scoreboard 2017, http://ec.europa.eu/growth/industry/innovation/facts-figures/scoreboards_en.

\section{Strengthening university education and research}

More needs to be done to improve the quality and attractiveness of researchers' training along with their career paths. Universities have an incentive to take on doctoral students, as their numbers count as a basis for funding, but with little regard to quality. Half of Poland's 40000 doctoral students do not actually work on their thesis, the graduation age is high, and the graduation rate is rather low (Figure 11). Training is based on the apprentice model whereby a habilitated professor oversees the student, but given that many Polish professors do not produce internationally competitive research themselves, their supervision is unlikely in many cases to guide students effectively towards high-quality research. After doctoral studies Polish researchers have to obtain a second degree, habilitation, among other hurdles to becoming a full professor, for which the average age is well above 50. During the habilitation, which typically coincides with the most productive and creative years for research, they have very little independence to set up their own research groups and supervise doctoral students. The government intends to grant a fast-track habilitation to winners of competitive international grants, especially European Research Council grants. But for now the link between research quality and career progression is weak. Repatriation of Polish 
researchers from abroad, like international academic exchange in general, is limited, although both NCN and the Polish Science Foundation offer a range of interesting grants for researchers from abroad who want to come to set up teams or do individual research in Poland. Academics' job situation is often very unstable, in particular in the early years, while more senior researchers enjoy job stability with little scrutiny (European Commission, 2017).

Figure 11. The supply of researchers is weak, $2015^{1}$

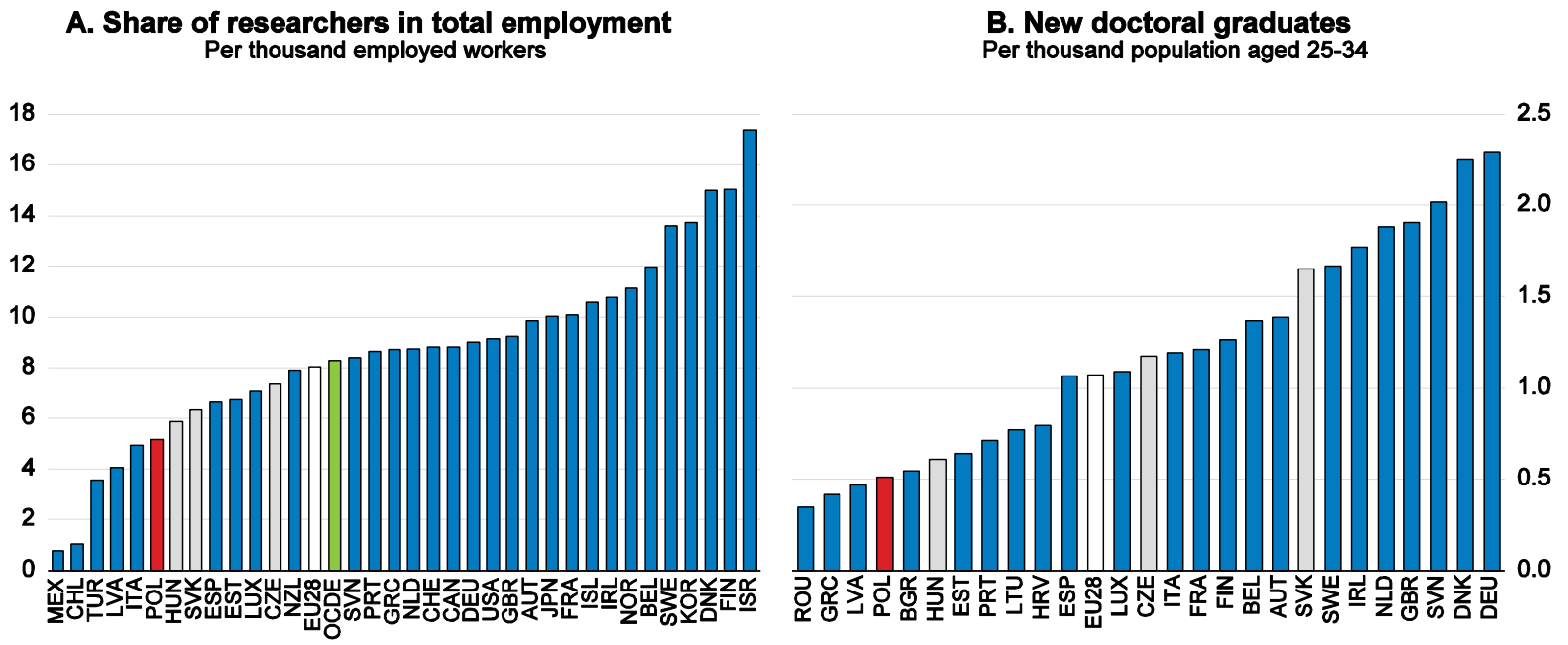

1. Or latest year available.

Source: OECD (2017), OECD Research and Development Statistics (database); European Commission (2017), Research and Innovation Observatory - Horizon 2020 Policy Support Facility, https://rio.jrc.ec.europa.eu/en/stats.

Building structured training in doctoral schools, as planned, while fostering mobility and collaboration across Polish and international universities would therefore be very welcome. Entry criteria to doctoral training should be tightened, and there should be training and guidance in both disciplinary knowledge and transversal skills provided by multiple senior researchers. These programmes could be linked to doctoral fellowships that should be awarded on a competitive basis. The Higher Education reform includes welcome plans to build doctoral schools with demanding entry requirements and mandatory remuneration for candidates along with broader access to grants and project-oriented funding. The reform should make sure that young researchers with a doctoral degree have full independence to set up research teams and obtain grants and that their further career development depends on their research and teaching performance. Reforms are needed to enable universities to offer well-remunerated entry-level positions for a limited but sufficiently long time to allow researchers to develop their work. This should be followed by a possibility to obtain a full professorship at the same university or elsewhere conditional on an evaluation of teaching performance and of research quality and impact by both faculty members and independent experts, possibly including from other countries. Further pay and career progression should depend on similar review mechanisms. Providing sufficient flexibility to combine a career in research with family life will be particularly important to attract women, who are relatively well-represented in lower-ranking positions, but become rarer at every step in the hierarchy. Female-headed teams also have lower chances to obtain grants. Developing a strategy to fight gender biases in science would help Poland use the full potential of females in research (European Commission, 2017).

Efforts to make recruitment procedures more open and merit-based should continue. Job offers at higher education institutions now have to be published online, and recruitments have had to follow clear procedures since 2011. However, higher education institutions are not obliged to inform candidates about eligibility and selection criteria or the composition of the selection panel, which rarely comprises external experts. There are no regulations defining minimum time periods between vacancy publication and the 
deadline for applications, the scope of feedback that unsuccessful applicants can receive or rights to appeal the decision. The common practice at universities is still to hire the initially preferred candidate, for example a former doctoral student, and the vast majority of researchers, more than $85 \%$, are employed at institutions where they have completed their doctoral degrees (Klincewicz and Szkuta, 2016). But mobility can have a positive effect on research productivity (Dubois et al., 2014). Strengthening recruitment procedures, by clearly defining the rights of candidates and appeal procedures, and requiring panel interviews with at least one external expert to hire academic staff would better ensure that positions are awarded to the best rather than internal candidates. Mobility should be an important quality criterion.

A multi-year plan is needed to increase funding for higher education and science while improving its efficiency. While spending per tertiary student increased by $43 \%$ between 2008 and 2013, it is still among the lowest in the OECD (Figure 12). The sector is very fragmented with many small, specialised institutions, although some consolidation is ongoing. Among more than 130 public higher education institutions, there are only 17 comprehensive universities and some 50 institutions that have less than 2000 students (European Commission, 2017). Building larger, more diversified universities, in particular in bigger cities, would ensure a more efficient use of infrastructure and staff. This could be done via voluntary, financially supported mergers. Integrating the best applied public research organisations and basic research-oriented institutes of the Polish Academy of Sciences into universities would also help to make better use of experienced research staff and infrastructure. It would help to expose students to excellent research capacity and to build a small number of high performing research universities, facilitating international visibility. The best performing universities could receive extra funding for a multiannual period awarded in a competition, as planned by the government. However, it is important to ensure that this does not involve less money for other higher education institutions, as sufficient breadth of good universities will be needed to provide the labour market and top research institutions with a wide pool of candidates with strong skills. Stronger mechanisms are needed to ensure that poor-quality higher education and research institutions are closed if they do not improve over time after receiving poor evaluations from the independent accreditation agency. Well performing universities need sufficient flexibility to use their funding to offer researchers attractive wage packages and career opportunities based on proven ability to build strong and stable teams.

Figure 12. Spending on tertiary education should be increased further, 2014

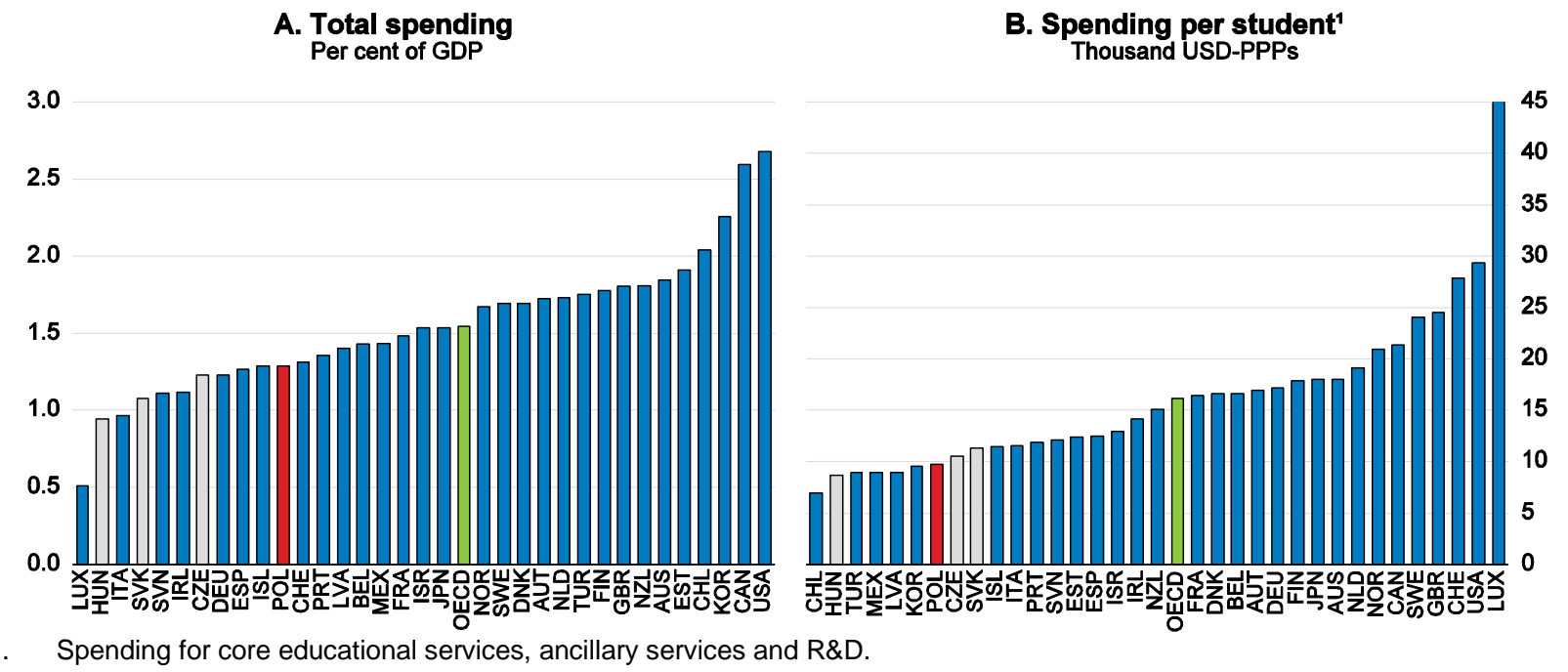

Source: OECD (2017), OECD Education at a Glance 2017 (database).

The effectiveness of funding allocation for research and higher education as a steering mechanism can be improved further. The Ministry foresees integrating many of the currently roughly 20 funding streams 
based on different criteria and allocating funding at the university rather than the faculty-level. This would reduce administrative costs and facilitate interdisciplinary work and universities' management flexibility. Moreover, moving from annual to multi-annual funding would further improve their scope for strategic planning. The share of competitive funding in the government science budget distributed through grants has gradually increased from around 45\% in 2009 to 60\% in 2015 (Klincewicz and Szkuta, 2016). Yet, the current formulae and indicators for allocating institutional funding are too complex and often tied to inputs rather than outputs, promoting research quantity rather than quality and impact. The Ministry's decision to stop rewarding points for publishing in journals with low impact is welcome in that respect. Ideally, there should be only a few indicators tied to outputs in a transparent manner, but they have to be known early enough to influence behaviour, unlike changes introduced towards the end of the 2013-16 evaluation period. There is also considerable room to increase universities' fundraising through collaboration with business and the wider community, adult education and voluntary giving. One way to stimulate this would be through a national competitive funding stream, akin to the Higher Education and Innovation Fund for England (European Commission, 2017).

Despite efforts to better engage business in vocational higher education, progress has been insufficient. Public higher vocational schools are sparsely spread over the territory and mainly present in former regional capitals. They suffer from low and declining student enrolment, a lack of short-cycle programmes and work-based learning opportunities as well as weak alignment with regional labour market needs. Most degrees are in social and medical sciences, with social science graduates in particular facing relatively poor labour market outcomes (European Commission, 2017). Poland needs a strategy how to engage with employers to develop strong vocational programmes throughout the country with a presence in all regions and major cities. In bigger cities these can be integrated into larger higher education institutions that also offer less occupation-specific programmes. In high performing systems, such as Germany or the Netherlands, the costs of study programmes are typically covered by the state, while the business partner pays a monthly salary or grant to the student-employee. Such a co-financed model would better ensure alignment of study programmes with labour market needs than the current system and fit the needs and interests of less academically minded students. Current plans to integrate internships that last at least six months would be a first step, but a more systematic integration of work and study throughout the programme and full co-financing with business should be the ultimate goal. Building such a system would require dedicated financing for an extended period and active engagement with employers. Vocational higher education institutions could play an important role in offering adult learning and cost-effective distance- or blended-learning models to reach students in peripheral areas and from lower socio-economic backgrounds (European Commission, 2017). They could contribute to training and R\&D opportunities for smaller companies corresponding to regional industry and labour market needs.

The government wants to improve international collaboration and significantly support international academic exchange as well as the process of internationalisation of Polish higher education and research institutes. It set up in October 2017 the National Agency for Academic Exchange (NAWA) to manage international academic exchange and attract foreign students and researchers to Poland, akin to institutions such as Campus France and the German Academic Exchange Service. It also wants to reach out to the Polish research diaspora to engage them in joint projects with researchers in Poland and motivate some of them to join Polish research institutions. Creating attractive career paths for researchers in Poland that are compatible with those in other countries and offering interesting grants for short stays in Poland will be crucial for success. Sending Polish researchers to foreign institutes will also be important. Both NCN and the Polish Science Foundation, FNP, have grants for international project teams and programmes to attract foreign researchers to Poland or entice Polish researchers abroad to return. Furthermore, there are plans to create a number of research groups in Poland jointly financed with the German government, which will cooperate with German researchers. 
A reform is underway to improve the management of some public research institutes. The Ministry of Science is set to build a network for 35 applied research centres, by centralising their investments in research infrastructure, human resources and intellectual property management. This could help improve efficiency. The Lukasiewicz Network will be responsible for managing research quality, commercialisation and international cooperation.

\section{Commercialisation of research results}

The government wants to focus on creating better incentives to commercialise research results. Researchers are mainly evaluated based on their publications, giving them little incentive to cooperate with industry or commercialise their research results. Enterprises, on the other hand, need secrecy until their inventions are marketable, and publishing results early is thus not always in their best interest. The government wants to give more weight to successful commercialisation in institutional and individual evaluations that determine public funding for Higher Education and Public Research Institutions and made first steps in this direction in 2017. There are also plans to allow doctoral students to use research results that they obtained while working for enterprises for completing their thesis. Professors and other experienced researchers should also be allowed to work part-time on commercial projects.

Technology transfer offices have gradually been set up in most Polish universities, but they are often underfunded and find it difficult to attract and retain qualified personnel. Some university technology transfer offices are very active in reaching out to local business and giving them advice on how to use the universities' know-how and research potential. Technology transfer centres throughout the country also collaborate to exchange ideas and good practices. However, many centres suffer from weak financing and have therefore trouble attracting and retaining qualified staff. A law passed in late 2016 stipulates that $2 \%$ of higher education funding has to be set aside for commercialisation of research results, some of which may benefit technology transfer offices. Merging technology transfer offices for universities that are nearby would help them reap economies of scale and organise research collaboration across institutions. Making it easier for higher education and public research institutions to commercialise research results could be an incentive in and by itself. But this requires easing administrative procedures and lifting important legal barriers.

One important issue is that assets of universities, including intangibles, remain under public finance law. To some extent this also holds for special purpose vehicles that many universities have created to commercialise some of their research results. Public finance law lengthens and complicates procedures. As an example: the value of patents or other types of know-how has to be established by external expertise. The university has to maintain an offer at this price for several months and can only reduce it after a fullfledged public procurement procedure. Since the market for innovations moves fast this can severely impinge on chances for successful commercialisation. It also reduces flexibility, as research institutions cannot accept a lower price for their know-how in return for their business partner renting some of their laboratory infrastructure, as an example. The system has held back universities' cooperation with small and medium-sized enterprises (SMEs), in particular, as they often cannot pay the price for university knowhow that was established through external expertise. They also need simpler procedures. Relatively simple transactions, such as hiring a patent attorney can require a public tender, although the 2014 public procurement reform brought some improvement by freeing universities and research institutes from standard public procurement routes if the order value is lower than 221000 euros. In many OECD countries higher education and research institutions' intangible assets do not belong to the public finance sphere, offering more freedom of operations.

Case studies underline the importance of openness to foreign capital and expertise to successfully commercialise research results. Politicians' and government officials' main aim is to develop domestic companies and employment through research commercialisation. Yet, success often requires speedy access 
to sufficient funding and specialised expertise and looking for the right partners worldwide can be essential (Box 1). Earning and newly won expertise will be highest when choosing a strong partner, whether domestic or foreign. This is especially relevant in a country like Poland with little domestic experience and expertise in research commercialisation.

\section{Box 1. A tale of two high-tech inventions}

Openness to partnering with specialist researchers and companies worldwide can be essential to commercialise scientific research successfully. Comparing Polish efforts to develop blue laser technology with the search for therapeutic applications of modified DNA particles provides suggestive evidence in this respect.

Polish researchers on the road towards a cure for cancer. In late 2010 researchers from the University of Warsaw were able to present breakthrough findings that have a good chance of making a significant contribution to the development of cancer vaccines. In essence, the researchers found a way to prolong the life of DNA particles, known as mRNA, helping to produce proteins and emulate the behaviour of healthy cells. The research, which started in the early 1980s, benefitted from partnerships with US universities. The findings were so significant that they led to the largest technology-licensing transaction involving university research in Poland to date. So far, German and French pharmaceutical companies invested altogether over USD 600 million. Importantly, they also provided expertise, e.g. with clinical trials. These industrial partners are highly specialised in the field, and no such expertise would have been available in Poland. Neither would Polish companies have been available to provide the necessary funding.

Poland in the race towards developing the blue laser. Compared to other colours blue lasers have a particularly high precision in pointing, cutting and burning, leading to a fierce international race towards the development of this technology. Thanks to breakthrough inventions in the 1990s Japanese researchers and companies were ahead of the game, and the US government invested considerable funds to avoid falling further behind. In the 1990s, in the midst of this race, researchers from the University of Warsaw pioneered a particularly effective method to grow Gallium nitride $(\mathrm{GaN})$ crystals, a semi-conductor material that turned out to be superior to others for mass production of high-quality blue lasers. One strategy would have been to directly commercialise this method, which was unique, patented and internationally renowned, and partner with Japanese companies and researchers to develop the method further. In fact, another researcher from the University of Warsaw, who later developed a commercially attractive alternative method to grow GaN mono-crystals, did partner with the leading Japanese company and was able to earn a significant amount with his academic spin-off for a number of years. Instead, the original Polish research team abstained from commercialising intermediate inventions, aiming for developing the blue laser technology by themselves with government funds of the order of PLN 30 million over 2000-04, but no help from leading researchers in the field or entrepreneurs familiar with commercialising research. In the end, their GaN crystal growth method turned out to be relatively easy to substitute and foreign competitors were soon able to reduce manufacturing costs with mass-production. The Polish team never managed to attract private funds at the necessary scale or be competitive with its cost structure and small-scale production. While it did develop a blue laser in the end, it is used for niche applications and never managed to gain significant market share. To this date it continues to produce on a laboratory scale.

Source: A. Kołodzjei, (2016) "Przełomowe odkrycie naukowców z UW. Koncerny już zapłaciły za nie ponad 600 mln dol” in money.pl http://www.money.pl/gospodarka/wiadomosci/artykul/szczepionka-na-raka-przelom-w-medycynie-mrna,207,0,2205647.html;

University of Warsaw Faculty of Physics (2016), "Towards therapeutic applications of mRNA - New Insights into translation and decapping", in eurekalert https://www.eurekalert.org/pub_releases/2016-11/fopu-tta113016.php; K. Klincewicz (2010), "The Blue Laser Project: Challenges for Technology Transfer in Poland" in: A.H. Jasiński (ed.), Innovation in the Polish Economy in Transition: Selected economic and managerial issues, Publishing House of the University of Białystok, Białystok, pp. 101-17.

\section{Developing enterprise and innovative activity}

\section{Stimulating innovative start-ups}

The government focusses a lot on financing high-tech start-ups, but more support for improving higher education and research may be a pre-requisite for success. It plans to develop venture capital financing for various stages of early firm development by providing almost PLN 3 billion of public funds. While earlier venture capital policy programmes have helped to develop the market, they had to be downscaled significantly because of a lack of viable projects. In fact, while financing is important and should be developed further, it is unlikely to be the immediate bottleneck. Support for venture capital has 
to come with a strong focus on basic and applied research as well as technology transfer and increased funding for that.

Institutions to support researchers and other entrepreneurs setting up their own companies are gradually emerging thanks to public funding. The government had trained so-called innovation brokers during the last EU Structural Fund financing period to build capacity at universities in research commercialisation. Candidates were sent to US universities where top-quality business incubators and seed accelerators develop scientific start-ups through mentoring, coaching and provision of financing and networking opportunities. Yet, the programme was interrupted during the switch-over of EU budget periods, which is symptomatic of a lack of a strategy ensuring continuity when external funds are abating. Nevertheless, an overall well-functioning business incubator landscape has developed in Poland thanks mainly to public support. A competition set up in late 2016 aimed at building more seed accelerator institutions that provide would-be entrepreneurs with training and support to develop a business strategy, network with larger enterprises to seek clients, access financing and eventually commercialise their products. The accelerators also make a small seed investment in participants' firms in return for an equity stake in the company. These initiatives are welcome, as expertise in supporting and mentoring start-ups remains scarce.

There are promising projects, including at smaller, less renowned research institutions, but capacity building is necessary to bring more of them to the market. Many inventions that have a potential to be commercialised successfully are shelved, because there is no tradition or expertise in industry-science cooperation to bring innovations to the market. The government plans to set up an Innovation Manager Academy to build expertise in companies how to set up and develop an innovation project. This is welcome, as there is still ample room for improvement regarding management practices in Polish firms, particularly domestic ones (Figure 13). More specifically, managing innovation and seeking out partners in the research community is a blind spot. Many business programmes financed by EU funds are now conditioned on collaboration with science, and this is showing first results. Training for managing innovation and science-industry cooperation will be a useful complement.

\section{Figure 13. The quality of management is relatively low in domestic firms}

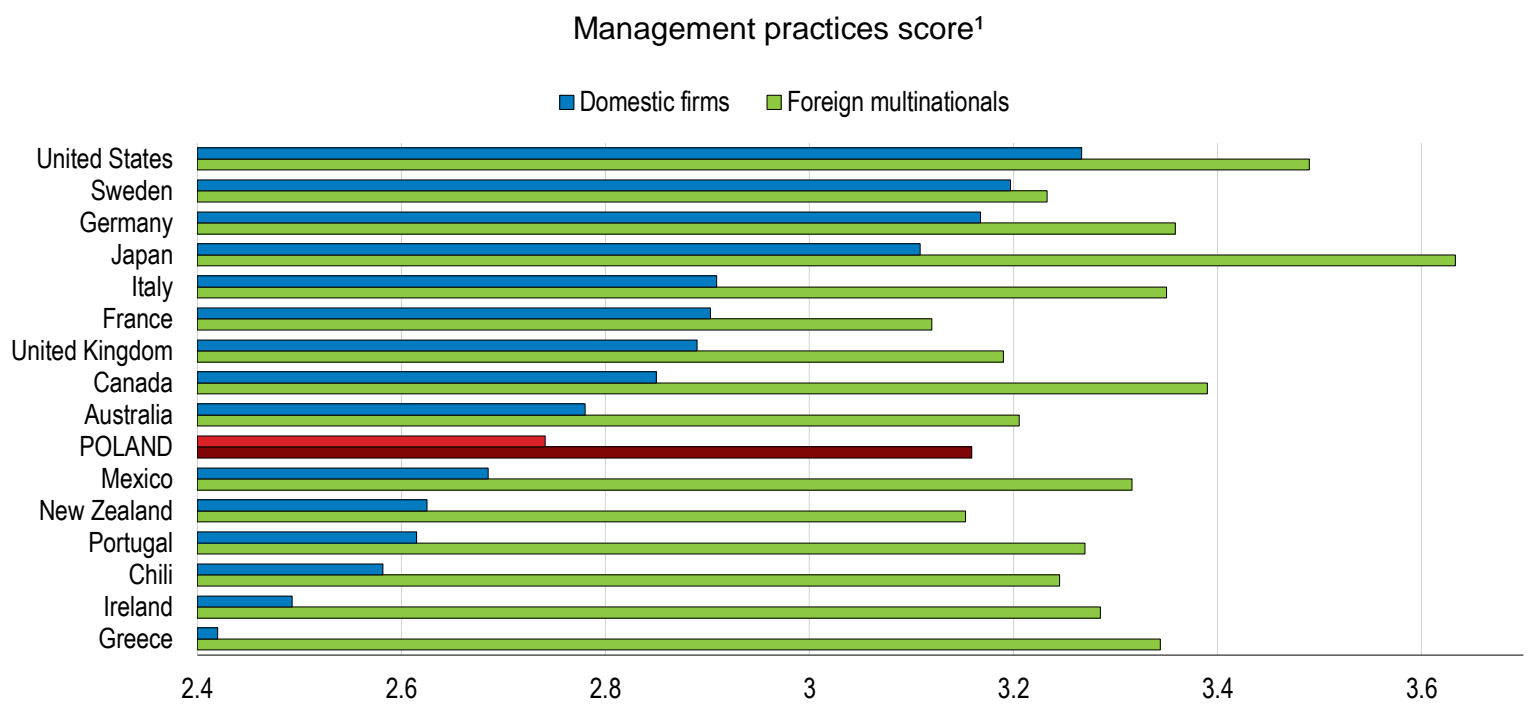

1. Scores are a measure of management practices across 5 key areas of management: operations management, performance monitoring, target setting, leadership management and talent management. Scores are scaled from 1 (worst practice) to 5 (best practice).

Source: Bloom, N., C. Genakos, R. Sadun and J. Van Reenen (2012), "Management practices across firms and countries", NBER Working Paper, No. 17850. 
More modern and systematic entrepreneurship training in universities is needed. Entrepreneurship training in higher education institutions has become more widespread. Examples of innovative learning methods do exist, including problem-based learning, business plan writing and even some degree programmes where the creation of a start-up is an integral part. Yet, classical lecturing remains the dominant method in most institutions. Entrepreneurship teachers would benefit from dedicated training to learn modern teaching techniques, including at leading universities abroad and through national and international networks and conferences. Promoting entrepreneurship research, which is largely absent from Polish universities, is also necessary. All Polish universities should appoint a senior manager responsible for entrepreneurship training and research commercialisation. The Innovation Council should work with higher education institutions to build a strategy for entrepreneurship training and support, which should become a part of the envisaged higher education reform (OECD, 2017).

\section{Promoting firm entry, growth and innovation through regulatory reform}

The government foresees the introduction of a simplified joint stock company to facilitate starting up a business. The idea would be to have very low capital requirements, possibly only 1 PLN, simplified registration online within 24 hours and light procedures to dissolve the company. Capital contributions would be possible in kind or in the form of labour. Shareholders would have contractual flexibility to define governing structures and rights attached to different types of shares, which would be easy to buy and sell. There would also be a provision to allow companies to issue stock options to employees. The hope is that this would be better adapted for start-ups than existing legal forms, which have higher capital requirements, are more cumbersome to build and wind up and less flexible in terms of shareholder rights, contributions and governance. However, very low capital contributions can impinge on investor confidence and access to financing. To partly address these issues, the company would be required to build reserves in the first years of operation, and payments to shareholders would be subject to a company solvency test.

Easing compliance with tax law and general regulations should also be helpful, but this should be weighed against the social and environmental goals pursued with regulation. Barriers to entry are still relatively high in Poland and paying taxes remains cumbersome, despite important improvements (Figure 14). The "100 changes for business" programme and the "business constitution" law foresee more legal certainty for firms when it comes to paying taxes and audits and a reduction of paperwork. The threshold for full accounting obligations will be lifted from 1.2 million euros turnover annually to 2 million euros, and enterprises with a turnover below $50 \%$ of the minimum wage do not even have to register. Start-ups will be exempt from social contributions for the first six months and after that will benefit from reduced contributions for two years. Companies will need to keep financial statements only for five years now rather than indefinitely. Ministries have to publish simple explanations of administrative rules and tax laws, whose observance will be sufficient to comply with the law. Further simplifications are set to follow. The challenge will be to simplify compliance with the law without giving up regulations that are crucial for good environmental, social and economic outcomes. As an example, the simplification programme foresees abandoning the need for a building permit for one-storey outbuildings and sheds up to 35 square meters. Given that weaknesses in the Polish land planning system have led to substantial urban sprawl, this measure is questionable. 
Figure 14. Setting up a business and paying taxes remain onerous

\section{A. Administrative burdens on start-ups remain relatively stringent despite improvements Index', 2013}

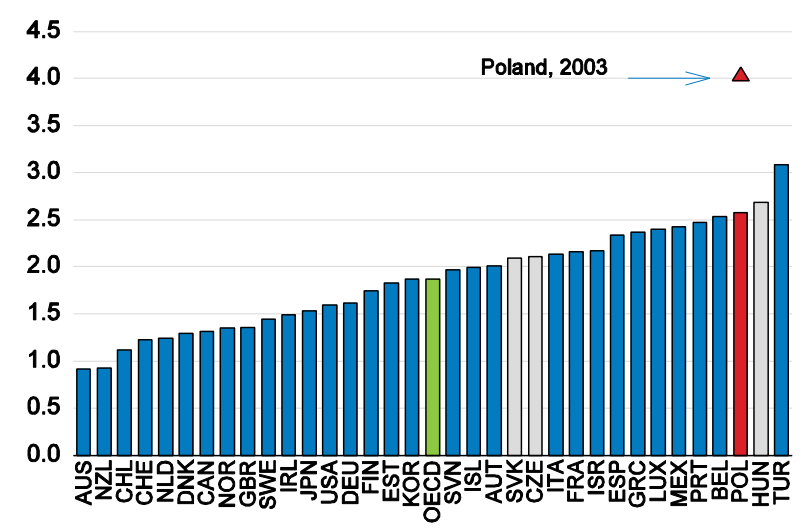

\section{B. Business tax procedures remain time-consuming 2016}

Time required required to comply with taxes (number of hours per year)

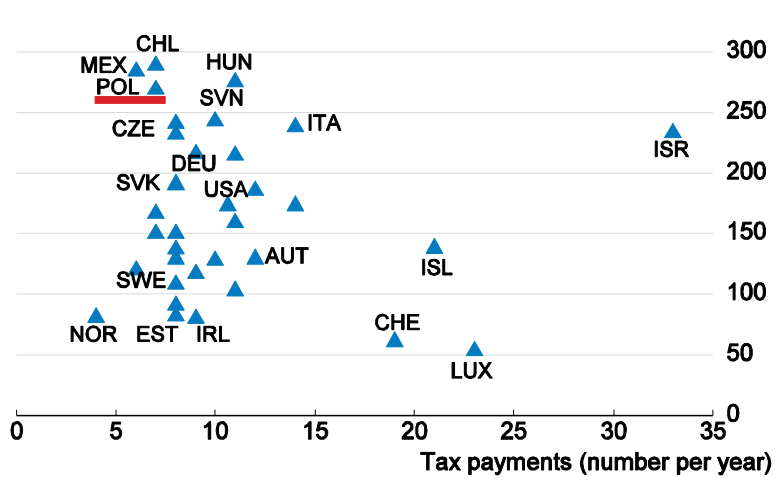

1. Index scale from 0 to 6 , from least to most restrictive.

Source: OECD (2017), OECD Product Market Regulations Indicators (database); World Bank (2016), Paying Taxes 2017 (database), the World Bank Group, Washington, D.C.

Simplifying procedures to apply for national and EU funds for innovation support would enhance take-up, in particular among SMEs. Procedures have been too complex, and a large share of applicants for EU funds administered by regions fails to comply with formal requirements. This is a particular concern for SMEs, and in the past a significant share of support from EU funds went to larger companies to absorb mature technologies (Kapil et al., 2013). There are improvements, though, as the central government has reduced paperwork and has moved largely to digital applications. It is also considering abandoning formal requirements as an initial filter. Instead, it would work with applicants on formalities in the substantive evaluation phase. There are now more face-to-face interviews in front of an evaluation panel to allow candidates to present their ideas in person. It would be useful to use the panel interviews as an opportunity to direct applicants with promising ideas towards consulting services, in case their projects need further work to ensure successful implementation. NCBiR has a reputation of providing relatively clear and straightforward information on its website and offers conferences to inform enterprises about the modalities of receiving support from EU funds. In contrast, information provided by some regions is complex, confusing and sometimes contains mistakes. The central government should consider providing regions with technical help to ensure clear and effective information and guidance for applicants. Regions have framework agreements for their R\&D programmes with NCBiR, and this cooperation could include support for re-organising procedures to improve success rates for promising SME projects.

A more transparent market for brokerage, consulting and mentoring services would help SMEs make better use of technology transfer. The government plans to simplify procedures to access the innovation voucher, which allows smaller companies to buy $R \& D$ from universities, and make it easier to find the right partners. In fact, OECD experience shows that strong brokerage bringing together SMEs and research partners is key for the success of innovation voucher-type programmes (OECD, 2010). Many companies hire expensive consultants to cope with the complex application procedures for EU funds. It would be useful to provide them with a register of innovation brokers, mentors and consulting companies describing areas of expertise and quality, for example through feedback from former clients or more formal certification. This would help companies find the services that are adapted to their needs and make the market more transparent, possibly helping to lower prices. Hands-on support from PARP or another government institution to clarify their needs and find the right partner would also be helpful. Currently, firms have to publish their demand for support from a research institution on a public competition database, a requirement set by the European Commission. But this will be too complex for many SMEs. In 
fact, universities and technology transfer offices reported that small firms often need direct counselling to understand how research institutions could help them. The requirement for SMEs to hold a public tender should be re-assessed, jointly with the European Commission.

Better supporting start-ups with risky projects requires more flexibility in evaluating and adjusting public programmes. In the past EU financing period funds were assigned to technology absorption, and mature projects close to commercialisation, mainly owing to risk-aversion of public officials granting support (Kapil et al., 2013). Research and development, in particular at earlier stages of the innovation process has a high probability of failure, while public finance law follows strict, often very inflexible criteria and can imply severe consequences, including in extreme cases jail sentences for public officials. This favours risk-aversion. In audits of innovation support the possibility of failure should be recognised as inherent to the process, and the assessment should use average success rates of R\&D at a similar stage of the innovation process as the yardstick.

\section{Agglomerations with strong firm networks, training and coaching services support innovation}

Research suggests that the presence of foreign firms benefits their Polish suppliers and competitors. Positive effects of foreign direct investment (FDI) on local firms may come from a variety of mechanisms. For instance, local firms may learn to imitate a new process or improve their product quality through observation or interaction with managers and former employees of foreign firms. They may also benefit from the entry of new professional services or suppliers from abroad. Several empirical studies find that the presence of foreign firms has positive effects on their Polish suppliers and competitors (Kolasa, 2008; Gorodnichenko et al., 2014; Hagemejer and Kolasa, 2011; Hagemejer and Tyrowicz, 2012). These effects are stronger in firms that invest in R\&D and other intangible assets, such as patents, licenses and software (Kolasa, 2008), underlining the importance of building knowledge to be able to absorb efficient technologies brought in by foreign companies. Hagemejer and Kolasa (2011) also show that Polish firms that export, have benefitted from FDI or have imported capital goods are larger, more productive, have higher capital intensity and pay higher wages. They also experience faster productivity growth.

Internationalisation induces firms to invest in $R \& D$ and innovate, which reinforces the positive impact on productivity. Boermans and Roelfsema (2015) show with data from Central and Eastern European countries that outsourcing is connected to product innovation, whereas exporting and FDI are associated with higher R\&D spending and more patenting. Similar results have been found in other regions. As an example, Aw etal. (2011) show that exporters from Chinese Taipei have a tendency to make complementary investments in $R \& D$ and invest more in training workers to increase innovative capabilities, reinforcing the positive effect on productivity.

The government plans to strengthen its investment promotion services, while providing Polish companies with more help to expand into foreign markets. The government has extended the mandate of its investment promotion agency to export promotion and bolstered its resources significantly. The plan is to set up centres abroad, which will support Polish firms expanding into foreign markets. A second aim is to strengthen its support for investors, including through a network of regional investment promotion offices that would assist investors in finding real estate, comply with regulations and obtain subsidies. This strategy is welcome, as coherent export support services have been lacking so far, and evidence suggests that high-quality investment promotion services tend to translate into stronger FDI inflows (Harding and Javorcik, 2013) with potential benefits for innovation and productivity.

The government foresees attracting foreign direct investments through various tax incentives and subsidies along with access to EU grants. This is part of the Strategy for Responsible Development developed in 2016, which intends to give preference to investments that involve R\&D, know-how transfer or local cooperation and supply networks. While targeting support on projects with such desirable features 
seems sensible, the risk is that tax incentives may involve considerable waste when investment would have taken place even without such costly incentives. In fact, Rodriguez-Pose and Wilkie (2016) find that direct public support for $R \& D$ is effective in attracting foreign $R \& D$. However, this effect is positively related to GDP per capita, aggregate R\&D spending and a quality of government index, suggesting that financial support cannot make up for otherwise unfavourable conditions (see also OECD, 2011). Public officials involved in investment promotion in Poland argue that while investment incentives are unlikely to be the main factor attracting foreign direct investment, it is difficult to do without them as long as they are offered in neighbouring countries. This suggests that coordinating with neighbours to reduce investment incentives could be beneficial for everybody.

While the evidence is mixed, some studies suggest that special economic zones have a positive impact on economic activity. Research on location decisions finds that the quality of infrastructure and service and industry agglomeration are the main factor attracting foreign firms, while special economic zones have no effect (Cieślik, 2005). Jensen and Winiarczyk (2014), on the other hand, find a positive effect of special economic zones on business creation that comes mainly from FDI, while the effects on employment, investment and income generation are small or insignificant, suggesting that the policy has not been successful in creating a sustainable, positive dynamic, helping poorer regions to catch up. This finding is in contrast to Cizkowicz et al.'s (2015) work. Exploring direct as well as second-round effects of special economic zones, their study suggests that they have a positive impact on employment and investment and, in the case of employment, there are positive spillovers on surrounding areas in the same county and on neighbouring regions.

The logistical support offered by special economic zones, which reduces investment costs, is a key factor determining their success. Such zones offer exemptions from taxes on income earned from the business activity, along with fully equipped plots on preferential conditions and in some communities real estate tax exemptions. The policy has recently been extended to 2026 and the government plans to allow for such tax exemptions also outside of the special economic zones subject to some quality criteria, which are yet to be defined. But beyond that some zones offer support with establishing links to local suppliers as well as tailoring educational programmes and training to the needs of investors. Given the importance of training and knowledge spillovers for innovation and productivity growth, this role is likely to be the key factor determining the zones' success. One example in this respect is the zone of Łódź, which was involved in developing vocational training with foreign investors and higher education programmes at local universities (Box 2). It is one of the best performing zones in terms of investment and employment volume and growth (Figure 15) and has won prizes for its education programmes.

\section{Box 2. Aligning education better with business needs - examples from the Łódź region}

The management of the special economic zone in Łódź, its companies and local universities with their business partners have been very active in organising training and education programmes tailored to the needs of employers along with opportunities to network amongst each other.

Apprenticeships for youngsters and experienced workers: Jointly with one of its investors, Haering Polska, a precision components supplier for car companies, and with the Polish-German Chamber of Commerce the management of the special economic zone set up apprenticeship programmes both for youngsters and for experienced workers designed to fit the companies' specific skill needs. The programmes offer practical training at Haering combined with school-based training at the Lifelong Learning Centre of New Technologies in Łódź, and chances to find permanent employment there upon graduation are very good. The company has also invested in its own centre for practical training at its Polish headquarters to provide both theoretical and practical training to its workers based on modern technologies.

University programmes preparing workers for logistics service centres and business process: outsourcing centres. At the demand of some of its foreign investors the special economic zone worked with the local university to develop a study programme, called linguistics for business, that prepares students for working in logistics service centres and in business process outsourcing centres, which have created significant employment in Poland 
over recent years. Technical vocational schools as well collaborate to prepare students for working in such centres.

Engaging business in designing study programmes and teaching: Together with partners from business the University of Łódź designed a new major in data analysis engineering. Students learn to exploit large quantities of data from different sources, so called Big Data, for business purposes. The programme involves practical work in enterprises. The university also works with companies and sometimes the public sector giving informatics students opportunities to develop mobile apps for them and present the result in their thesis. In some cases this has helped the university to sell technology licenses. There are also increasing numbers of practitioners who lecture.

Providing opportunities to build networks: The management of the special economic zone organises events that allow local businesses to meet foreign investors, such as business mixers, to facilitate business development.

Figure 15. The Łódź special economic zone has performed particularly strongly, 2005-15

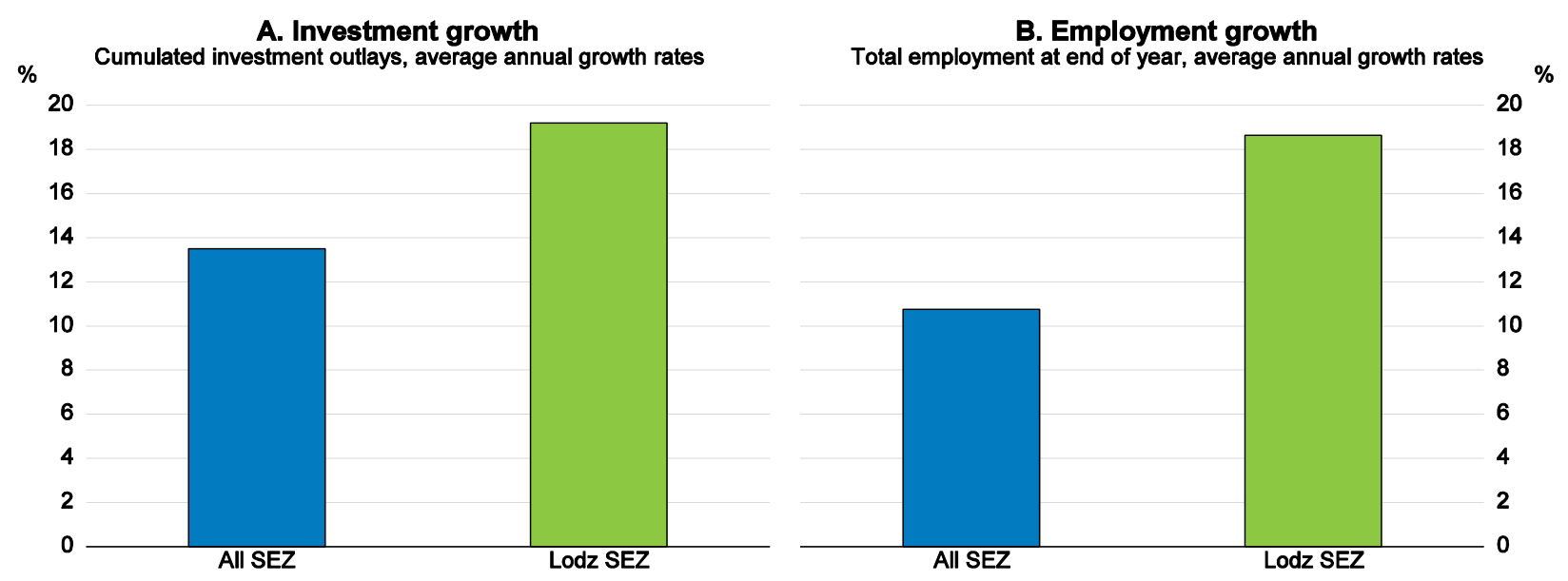

Source: Cizkowicz, P. M. Cizkowicz-Pelaka, P. Pekala and A. Rzonca (2015), "The effects of special economic zones on employment and investment: Spatial panel modelling perspective", Narodowy Bank Polski Working Paper, No. 208, Warsaw; Statistics Poland.

The example of Łódź suggests that proximity to high-quality education and research centres is key for attracting investment and creating employment. While the management of the special economic zone of Łódź is particularly active, its location at a crossroads of key transport routes is certainly another plus. Unlike other special economic zones it is close to universities and research centres. The regional vocational school also has a reputation for being particularly well managed and open for new partnerships with enterprises. Creating a good vocational school with strong business partnerships may be possible to replicate in more remote areas and can serve as an inspiration for other regions. It would be useful to create a systematic exchange of good practices among special economic zone management agencies.

To promote knowledge exchange and productivity in firm agglomerations, Poland like other countries, tries to develop clusters. The implicit hope is often to create the next Silicon Valley by promoting a local concentration of interconnected firms, suppliers and research institutions. Yet, while there is evidence for positive agglomeration effects on innovation (Carlino and Kerr, 2015), it is much less clear whether public policy can create or reinforce this (Chatterji et al., 2014). Some studies indicate that cluster policies have helped to promote innovation and attract well-performing firms (Engel et al., 2012; Falck et al., 2010; and Fontagné et al., 2010). Yet, Martin et al. (2011) find no positive effect of a smallerscale French cluster programme. Likewise, Nishimura and Okamuro (2011) find no significant effect on productivity from participating in Japanese clusters, while collaborating with a national university or partners outside of the cluster does increase $R \& D$ productivity. This suggests that collaboration with research partners as such can be more important than participation in a cluster. Burger et al.'s (2015) results indicate that cluster organisations mainly help attract economic activities with less specific location 
requirements, such as production plants, sales and marketing offices, rather than high value-added activities that occur in headquarters or R\&D facilities.

Polish cluster initiatives, technology parks and other structures supporting innovation through firm colocation are relatively recent, and few have proven effective so far. Most of them have been set up since 2010, often with the support from EU funds. In many cases their innovative activity and orientation towards foreign markets is low and their financial viability without subsidies is questionable. Many lack a common business strategy for their members and make insufficient use of mentoring, coaching and business development services. The management of these structures and the ministries that sponsor them often lack information about innovative activity and economic results of the firms that they are serving, precluding effective evaluation (NBP, 2016; NIK, 2016).

Going forward the central government plans to focus support on a small group of key clusters. These were chosen in a competition to identify the most promising cluster initiatives in terms of size, management quality, innovative activity and presence in foreign markets. Public support is meant to help them expand further into foreign markets. Given that little is known about effective policies to support clusters' innovation output and productivity, it seems indeed sensible to concentrate on framework conditions, such as internationalisation, investment in infrastructure and training. This should include efforts to improve cluster management, as well as links to research institutions. Clusters, technology parks and similar initiatives that receive public support should be required to set up a plan how to increase their own earnings and those that fail to gradually attain viability by themselves should eventually lose their subsidies. A robust evaluation framework is needed to better understand what works, but trying to build firm agglomerations in remote areas far from research and training institutions is unlikely to be effective.

\section{Adult learning and vocational training}

Special efforts are needed to help Poland's many small and relatively unproductive firms to become more efficient; enhanced education and training will be essential. Focussing on high-tech start-ups will not be enough to lift the performance of the Polish economy. Relatively unproductive small firms operating in mature sectors employ a large share of the labour force, and they need support to modernise and improve their efficiency. Education and training for their managers as well as their general workforce will be key to strengthening their capacity to adopt new products, production processes and organisational practices. The results of 15 year-old pupils in reading, maths and sciences have improved since comprehensive education was increased by one year in the late 1990s with strengthened curricula, according to the Programme of International Student Assessment (PISA), a skill test organised by the OECD, and are now somewhat above the OECD average. There are also fewer students with particularly weak skills. Yet, data from the International Adult Literacy Survey (PIAAC) reveal that the share of adults with exceptionally weak literacy, numeracy and digital skills, who struggle to understand even simple texts or basic algebra, is greater in Poland than in other OECD countries. At the same time participation in adult learning is low, in particular among those who need it most, older workers and adults with low educational attainment. The share of firms that send their staff on training is also much lower than in other European countries (Figure 16). 
Figure 16. Lifelong learning is underdeveloped, especially for low-skilled and senior individuals

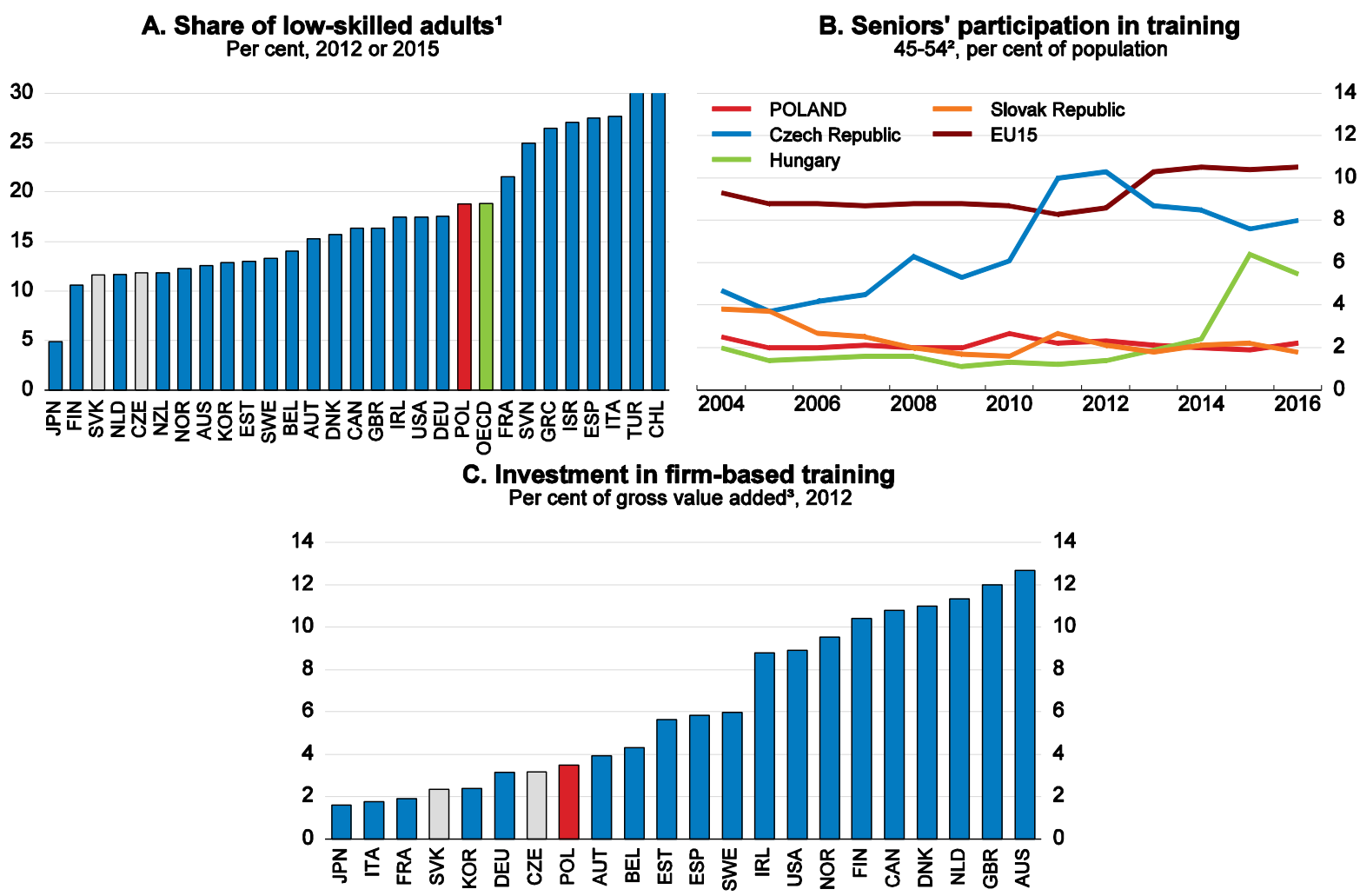

1. Share of adults scoring below level 2 in the PIAAC reading proficiency scale.

2. Percentage of individuals having had training in the 4 weeks preceding the survey.

3. Firms' investment in formal and on-the-job training.

Source: OECD (2016), Skills Matter: Further Results from the Survey of Adult Skills, OECD Skills Studies, OECD Publishing, Paris; Eurostat (2017), "Education and Training Statistics", Eurostat Database; OECD (2016), OECD Science, Technology and Industry Scoreboard (database).

The weakest students are often concentrated in vocational education. PISA and PIAAC results of pupils and graduates of basic vocational schools - which unlike technical vocational schools do not allow graduates to enrol directly in university - are weak. In fact, for adults they are only marginally higher than for those who completed only lower secondary schools at most (Figure 17). The government has recently increased the mandatory school starting age from six to seven. It also changed the school structure in 2017 by abolishing middle schools and extending primary school from six to eight years, reducing comprehensive education by one year. Basic vocational schools will be replaced by so called sectoral schools, where students would receive a first professional qualification after three years and a second qualification after two more years. At that point they would also be allowed to take matriculation (matura) exams opening the way to tertiary education, essentially the same exam as in general upper secondary schools, although with a possibility to replace one subject with a practical exam in the student's occupational orientation. The government hopes to attract better students to these schools, as qualifications after the two cycles would be close to those in technical schools, which have a better reputation. A better way to offer attractive qualifications in line with labour market needs and with students who prefer practical to academic training might have been be to offer a matriculation exam with an emphasis on practical skills in the students' vocational specialisation instead, akin to berufsmatura in Switzerland. Employers could have a strong involvement in setting the practical part of the exams, which would open the way to vocational tertiary education in the students' specialisation, while further exams could be required to enter more general academic fields. 
Figure 17. The skills of students and graduates from basic vocational schools are weak, 2012

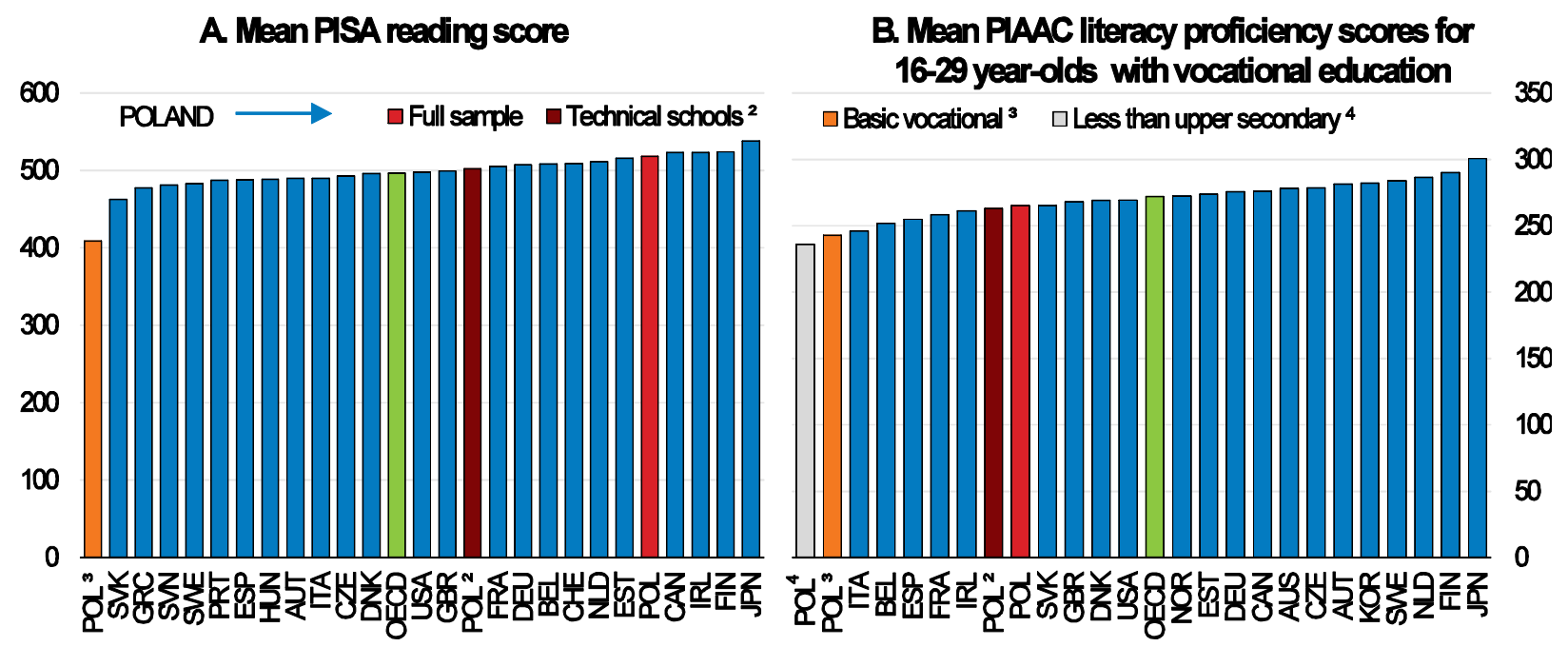

1. The data are based solely on Flanders for Belgium and on England and Northern Ireland for the United Kingdom.

2. Mean reading score for 16 year-old students of Polish technical schools (Panel A) from an optional national study for the first grade of upper secondary school (16 year-olds) complementing PISA and mean PIAAC literacy proficiency score for Polish adults having attended technical schools (Panel B).

3. Mean reading score for 16 year-old students of Polish basic vocational education (Panel A) from an optional national study for the first grade of upper secondary school (16 year-olds) complementing PISA and mean PIAAC literacy proficiency score for Polish adults having attended basic vocational education (Panel B).

4. Mean PIAAC literacy proficiency score for adults with less than upper secondary education.

Source: OECD (2013), OECD Skills Outlook 2013 (database); OECD calculations.

More efforts will be needed to attract highly qualified pedagogues to sectoral schools through attractive pay and career prospects, especially as a large part of the teaching workforce is set to retire. Attracting more teachers who combine strong teaching skills with up-to-date industry experience, for example maintained through part-time work in firms, will also be crucial. The recent decision to lift caps on pay for practitioners teaching in vocational schools is helpful in that respect. Learning programmes should be adjusted so that math, Polish and ICT classes fit the training context and professional specialisation of vocational students, which has been shown to strengthen motivation and learning outcomes.

More has to be done to convince workers and firms of the benefits of training. Surveys show that more than $60 \%$ of Polish firms try to recruit workers who are already well-adapted to their jobs without much of an intention to develop their skills. Likewise, many Polish workers do not engage in training because they do not see benefits for their labour market situation (Worek et al., 2015). More than 60\% of adults did not want to participate in training according to data from the OECD Survey of Adult Skills, compared to around $40 \%$ on average in participating countries. Survey data reveal that more than $75 \%$ of Polish firms complain that they cannot find personnel with skills corresponding to their needs and $30 \%$ of firms that do not invest in training point to a lack of training measures that suit their requirements (PARP, 2015). These employers need to be convinced that their own engagement is required if they want to be able to count on workers with the skills they need. There are examples of firms in Poland who benefitted substantially from setting up apprenticeship-type programmes for youngsters and adults in collaboration with vocational schools building on the German experience (Box 4). The government can use these to advertise their benefits. 


\section{Box 3. Firms addressing skill gaps by sponsoring dual vocational education programmes}

The German-Polish Chamber of Commerce has supported a number of companies to introduce dual vocational education programmes, combining practical training in the workplace and theoretical education in vocational schools. This helps firms deal with their skills needs by training workers themselves. While Germany has a long tradition in this type of training, Poland is still struggling to establish closer collaboration between vocational schools and employers. In the cases described below, the Chamber has acted as an intermediator, helping companies find partner schools, design curricula and advertise the programme in schools and in educational fairs to attract motivated young people as apprentices. The Chamber also monitors the training, secures close contact between the schools and employers and designs and organises exams. Successful graduates obtain a Polish and a German VET certificate. Participating companies appreciated being able to tailor the education programme to their needs and screening their apprentices during work periods. This helps them to shape their trainees' abilities and establish a close link with them to benefit from their skills in the long term, by hiring them upon graduation for instance. Examples for education programmes built in this way include the following:

Mechatronics. The Polish affiliate of German home appliances producer Bosch, experiencing difficulties with finding technicians with skills at the crossroads of mechanics and electronics, set up an educational programme combining the two, mechatronics. It collaborates with a local vocational school at its Poznań headquarters. The programme is designed to help theoretical and practical skills in programming, design, assembly and maintenance of mechatronic devices and systems. The company directly influenced the content of the programme, and the best graduates were offered a job in the company upon graduation.

Industrial mechanic and automobile mechatronics. Confronted with a similar skills gap the Polish bus producer Solaris built partnerships with vocational schools at its different production sites to train industrial mechanics and automobile mechatronics. Specifically for the practical training of its mechanics it installed equipment for welders.

Tool makers and machine operators. Phoenix Contact, a specialist in industrial automation, interface and interconnection solutions, has sponsored apprenticeships in different fields since 2013. The company pointed out that training apprentices at its workplaces, rather than relying on graduates of school-based vocational education who did their practical training in school workshops, was an investment that helped to save on firm-specific training of workers in the longer run.

Apprenticeships sponsored by Volkswagen. Volkswagen is one of the pioneers of dual education in Poland and has sponsored apprenticeships in mechatronics since 2002. It is the biggest employer of apprentices at the secondary level in the Poznań region, training youngsters in five different professions.

Dual education at the tertiary level - mechanical engineering. Building on their experience with apprenticeships for students at the secondary level, Volkswagen, Solaris and Phoenix Contact have been jointly sponsoring dual tertiary studies of mechanical engineering in collaboration with Poznań University of Technology since 2014. At the same university there is a specialisation in automation and robotics sponsored by Volkswagen and Phoenix.

The government has taken various initiatives to engage employers more in training, but this has been hindered by relatively weak and dispersed employers' associations. Given rising skills shortages, employers' interest in training workers has risen recently. The government is currently holding seminars with employers from a large range of sectors, including sectoral skills councils set up by Polish Agency for Enterprise Development, PARP, to identify the need for new training programmes and develop guidelines for schools and employers to work together, as there is little experience with such cooperation. This should be a priority. The regions and the central government should actively reach out to small companies, whose engagement is often particularly weak. At the same time, they are set to benefit considerably when providing their inputs in programme design to meet their needs. Taking on vocational students as workers who gain competencies in modern technologies and management thanks to high-quality vocational schools would help these companies develop their capacity to innovate and grow. Many shy away from the investment costs of taking on apprentices, though. One solution for them would be to pool their resources with other companies to equip training centres; governments should help organise such efforts. In Australia, small and medium-size companies organise so called Group Training Organisations, which select and recruit apprentices, place them with host employers and manage employer responsibilities as well as quality (OECD, 2016c). They also provide mentoring and guidance. Joining forces in this way could help Polish SMEs to benefit from apprenticeships, while controlling the costs. The government should also develop educational material to convince companies that training workers is an investment that 
pays. A German study (BIBB, 2015) comes to the conclusion that there are considerable net benefits to taking on apprentices in the longer term, and some employers recuperate their cost already during the training period, as apprentices contribute to regular work.

The Polish government plans with the OECD to develop a skills strategy involving early childhood and compulsory education, the whole government and stakeholders, and this is welcome. Basic skills should feature high on this agenda, as Poland lacks a strategy to fight illiteracy. Strong basic skills are essential for adults to find high-quality employment and for workers to contribute to productivity growth of their firms. In fact, while unemployment is high among workers with low literacy and numeracy skills, a considerable share of them are employed (Figure 18). The share of managers and tertiary graduates who can barely read simple texts or solve basic mathematical tasks is also high, a serious limitation of their innovation capacity. Low literacy has negative stigma; hence, reaching those in need of further training requires a special approach. Many OECD countries, including Germany, France and the United Kingdom, have developed basic-skills strategies that can serve as an inspiration for Poland. They include information campaigns to raise awareness, professionalization of basic- skills teachers for adults, partnerships with schools and employers to reach workers and parents with weak literacy, as well as training for job-search assistants and continuing-education teachers to identify clients with weak basic skills (OECD, 2016a). Basic-skills training combined with practical work experience in firms can be particularly helpful to motivate candidates. The government's pilot project to build a network of local adult learning centres focussing on low-skilled and inactive adults with regular evaluations is welcome.

Figure 18. Low skills are pervasive and weigh on labour market outcomes, 2012
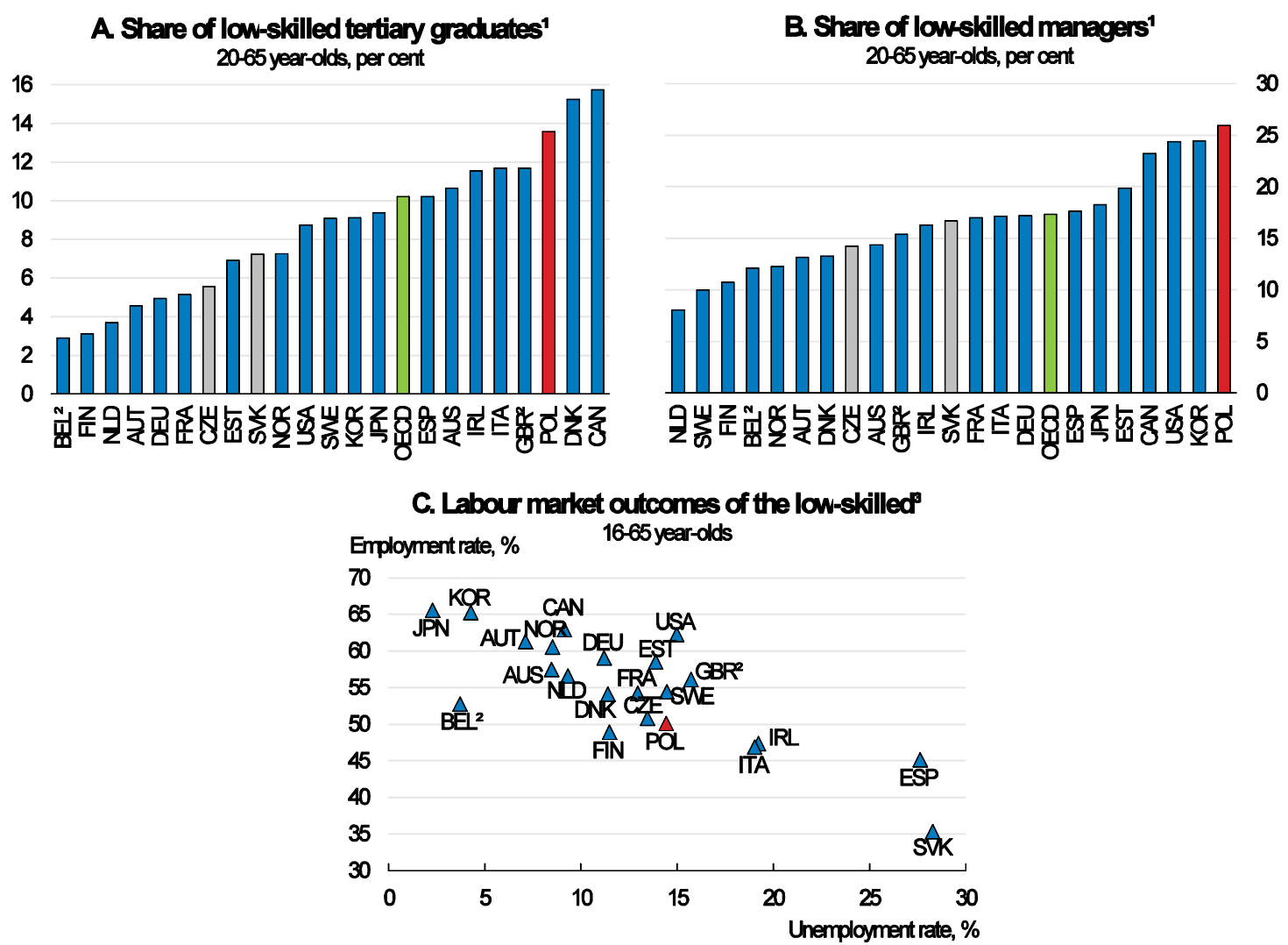

1. Share of tertiary-graduated adults (Panel A), and managers with at least upper secondary education (Panel B), scoring below level 2 in at least one of the PIAAC proficiency scales, i.e. literacy, numeracy and problem-solving in technology-rich environments.

2. The data are based solely on Flanders for Belgium and on England and Northern Ireland for the United Kingdom.

3. Share of adults scoring below level 2 of the PIAAC scale of numeracy proficiency.

Source: OECD calculations based on OECD (2013), OECD Skills Outlook 2013 (database). 
Stronger efforts are needed to improve participation in adult learning and ensure its quality. Over recent years the government has taken a number of initiatives to improve participation in adult education and training. Rather than attending full-time vocational schools, adults can now obtain new qualifications by enrolling in shorter courses, which can be part-time and modular, making it easier to reconcile training with work. The recently adopted integrated qualifications framework describes knowledge, skills and competences associated with formal qualifications. The hope is that this will make it easier for employers to choose training measures adapted to their needs, promoting stronger participation. The framework will also facilitate certifying informal and non-formal learning, such as training on the job, making it easier for experienced workers with little time for formal training to obtain further qualifications. The framework is also used to accredit certifying bodies that award qualifications through exams at the end of training programmes. The hope is that this would serve as a quality signal, making the training market more transparent. However, progress has been slow, and so far only a handful of measures have been accredited. Germany has private certifiers, which are approved by a central agency. Since 2016 Poland has used a similar system to accredit providers of training and other enterprise development support services, such as consulting and mentoring, through certified private accreditors. Accreditation is as prerequisite for making these services eligible for financing with EU regional funds, and inclusion in a databank set up by PARP is meant to make it easier for firms and training candidates to find what they need. PARP reviews accreditation certificates and performs on-site audits with a staff of five people to ensure service quality. This is welcome progress. This new approach should be evaluated and extended to make accreditation a prerequisite for receiving other types of public subsidies as well. Yet, more staff may be needed to ensure effective quality control.

\section{Strengthening demand for innovation through public procurement}

The government wants to use public procurement as an instrument to promote innovation by creating sufficient demand, but this requires a step change in procurement practices. The volume of public procurement is indeed substantial, amounting to 12\% of GDP in Poland in 2015, but like household demand it is mostly focussed on low price. There is little appetite for sophisticated technologies (Figure 19, Panels A and B). Only $7 \%$ of awarding entities reported having been involved in public procurement for innovative products or services between 2007 and 2010, and only 5\% of firms (Starzyńska and Borowicz, 2012). The lowest price was long the only criterion used for contract award in the overwhelming majority of procedures, more than $80 \%$ in 2014 , before it became mandatory to apply at least one additional criterion (UZP, 2015). Many government officials involved in public procurement pointed out that marketproven products reduce the risk of appeals and are easier to defend to auditors (Starzyńska and Borowicz, 2012). More generally, adopting new solutions always involves the risk that these might prove inferior to proven ones. In particular, when large sums are involved it can be appropriate for public buyers to weigh this risk against opportunities associated with promoting innovation. Beyond that, favouritism is seen as pervasive, which can discourage new and innovative firms from participating in public tenders (Panel C). Capacity also seems to be an issue as public buyers cited their employees' difficulties in establishing objective evaluation criteria for innovative projects. Complex procedures were cited as a barrier for small companies to participate in public tenders (Starzyńska and Borowicz, 2012). The Polish Agency for Enterprise Development offers SMEs training and counselling to help them participate in public procurement procedures in Poland and abroad. 
Figure 19. Demand for innovation is low, 2016-17

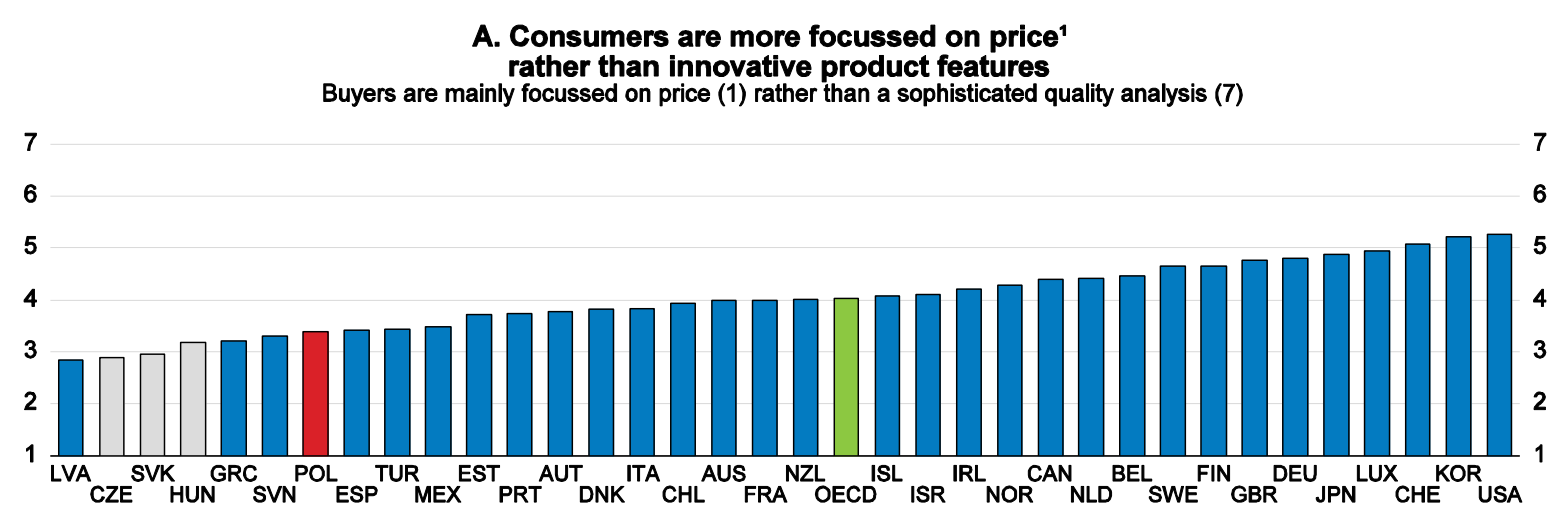

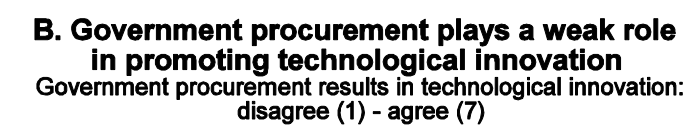

5

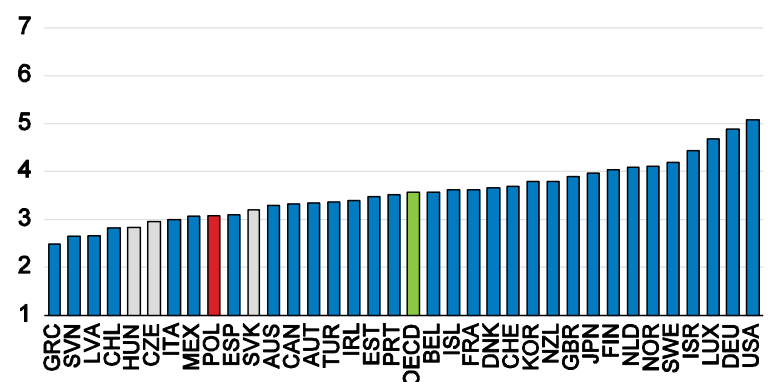

C. Favoritism is seen as pervasive Government officials favour well-connected firms (1) or are neutral (7)

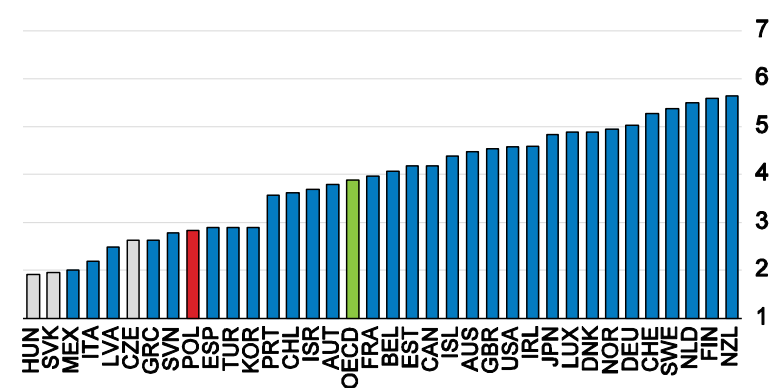

Source: World Economic Forum (2017), Global Competitiveness Index 2017-18 (database).

Recent reforms should help to gradually strengthen the role of quality standards in public procurement and make it easier to favour innovative solutions, provided capacity is built. Since 2014 at least one secondary criterion is required for contract evaluation in addition to price. Yet, first results suggest that relatively simple criteria, such as delivery dates or payment terms, have been used in more than $60 \%$ of the cases. Quality, functional requirements and knowledge or experience were used in less than $15 \%$ of the cases until mid-2016. Yet, a 2016 law requires contracting authorities who want to give a weight of more than $60 \%$ to the price criterion to specify quality standards and provide evidence on how they take lifecycle costs into account. Since then the use of quality standards and technical requirements in public procurement seems to have increased. The obligation to take life-cycle costs into account should give more room for innovative solutions to succeed, such as energy-efficient products, which often combine higher purchase prices with lower operating costs. Technical and competitive dialogues as well as negotiated procedures allow public buyers to discuss feasible quality standards and design features with potential suppliers before defining the subject matter of the award, making it easier to look for innovative solutions. Yet, these procedures are complex and have only rarely been used in Poland. The government intends to launch several pilot, pre-commercial procurement procedures in coming years, for example to harness the potential of young software developers. In addition, there are a few examples of innovation through public procurement procedures (Box 5). Yet, stronger capacity is needed for more widespread use of public procurement for innovation. The public procurement office offers training to help contracting authorities deal with innovation and other secondary public procurement objectives and it advertises best practices. In addition, technical help from the central government for smaller contracting authorities with less experience would be helpful as well as making it easier for them to launch joint projects through harmonised online tools. Establishing a national database of qualified consultants should be considered as well (OECD, 2016a). 


\section{Box 4. Innovation through public procurement in Poland}

\section{SOLARIS - a synchrotron radiation facility in Kraków}

The first Polish synchrotron radiation facility SOLARIS was inaugurated at the Jagiellonian University in Kraków in 2015. Synchrotron is a unique man-made source of electromagnetic radiation, which has supported cutting-edge research in physics, chemistry, material science, medicine, geological and environmental sciences, structural genomics and archeology. The Polish synchrotron is the first research infrastructure of such substantial size in Central and Eastern Europe, providing state-of-the-art research opportunities for diverse and multi-disciplinary groups. Beyond research benefits can include education and training opportunities, creation of high-tech companies and services, and product as well as process development for research oriented industries.

\section{The Regional Center for Water and Sewage Management, city of Tychy}

The Regional Center for Water and Sewage Management in the city of Tychy is an example of an institution with a long-term commitment to sustainable public procurement. The Center has transformed its highly polluting sewage treatment plants into one of the most modern and environmentally friendly facilities of its kind in Poland and Europe. Through green and innovative public procurement, setting high standards for energy consumption and reducing emissions, the Tychy Center for Water and Sewage Management has become a leader in eco-innovation in waste water treatment, renewable energy generation and management. Biogas is the primary source of renewable energy during the production of electricity and heat in cogeneration. Currently, the energy consumption of the sewage treatment process is only $0.33 \mathrm{kWh} / \mathrm{m} 3$ of purified wastewater. Local nuisance noise has also been reduced by using blowers based on technology applied in Boeing jet aircrafts. The Center not only fully meets own energy needs, but is also able to support other city infrastructure.

The public procurement reform also simplifies procedures, which should promote participation of SMEs. It encourages the division of orders into smaller parts to make it easier for smaller enterprises to compete, although this can also be misused to circumvent public procurement obligations, and that should be closely monitored. It also makes e-procurement mandatory as of 2018. Documentation requirements are simplified, and relying on third parties to comply with some of the requirements of public procurement procedures, e.g. concerning professional qualifications or experience, will now be allowed.

Demand for information and communication technologies is low, as is capacity to use them. Polish enterprises make little use of cloud computing services, the number of both fixed and broadband internet subscriptions is low and e-government should be further developed (Figure 20). 
Figure 20. ICT penetration is low, 2016

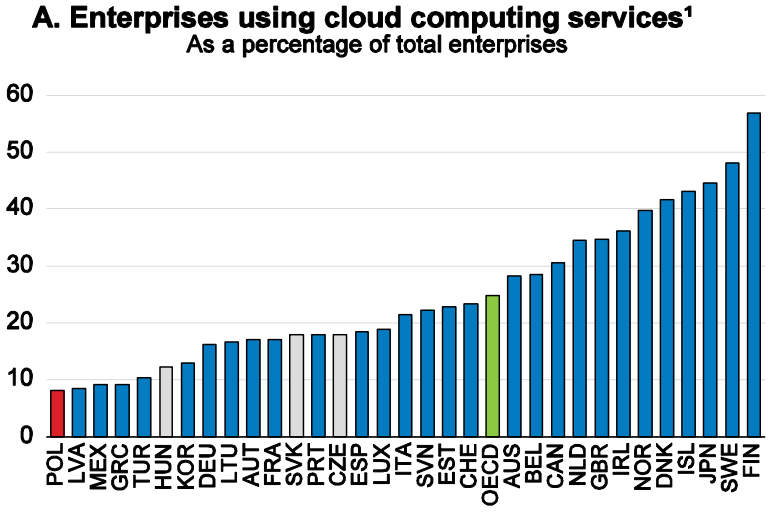

C. Wireless broadband connections for households Subscriptions per 100 inhabitants

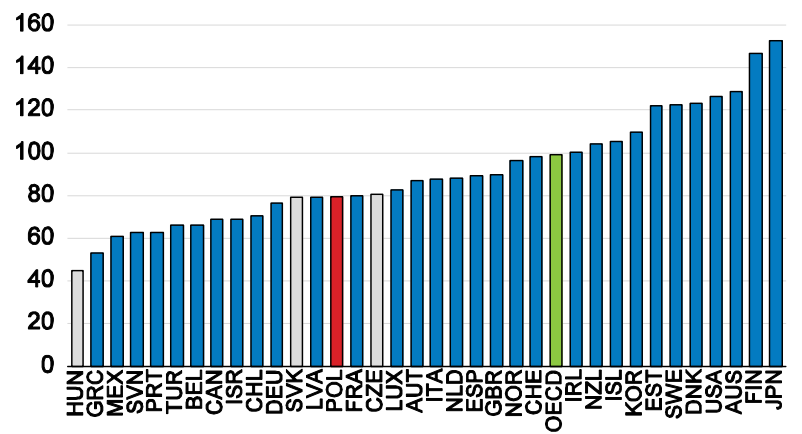

B. Fixed broadband connections for households Subscriptions per 100 inhabitants

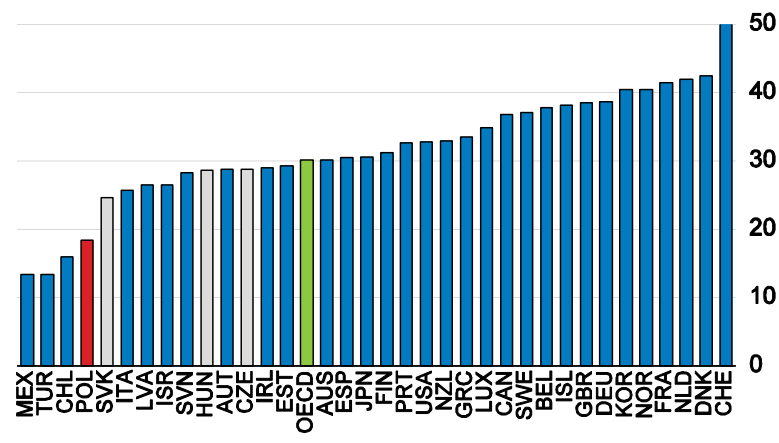

D. E-interaction with public authorities ${ }^{2}$

Per cent of total population

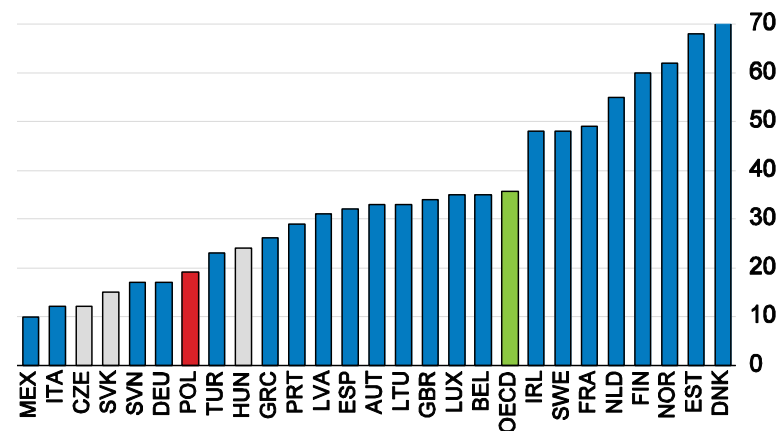

1. Cloud computing refers to ICT services used over the Internet as a set of computing resources to access software, computing power, storage capacity and so on.

2. Share of individuals who used internet to send filled forms to public authorities in the 12 months preceding the survey.

Source: OECD (2017), OECD Digital Economy Outlook 2017, OECD Publishing, Paris; OECD Broadband Portal, http://www.oecd.org/sti/broadband/broadband-statistics/; OECD (2017), OECD Government at a Glance 2017, OECD Publishing, Paris.

The government has developed a digital strategy to promote e-government and a nationwide epayments system. The strategy aims to improve public-sector efficiency and the quality of public services and to promote cashless payments with a view to fighting the informal economy and enhancing tax compliance. Elements include the creation of a single email-box for citizens to communicate with public services, including for delivery of official documents and compliance with reporting obligations; eidentification to facilitate information exchange between citizens and the government, digitalisation and simplification of benefit and tax payments, in particular social contributions; and improved health-care services through digital information exchange concerning patient profiles and treatment histories between providers. The strategy also foresees the promotion of cashless payments between the public sector and citizens as well as within the private sector, the development of a nation-wide e-payments system, and development of e-billing and e-receipts. The government sees the implementation of this strategy as an opportunity to promote the development of new technologies in Poland and plans business incubators, seed accelerators and clusters surrounding e-billing services and block-chaining technologies. However, it will need to be accompanied by effective ICT training to enhance the capacity of Polish citizens to use these technologies. The planned Foundation of the Industry of the Future, mentioned above, could play a useful role in that respect. 


\section{Recommendations to strengthen innovative capacity in Poland \\ (Recommendations that appear in the Key Recommendations are in bold and italics)}

Higher education and research

- Enhance industry-science collaboration. Continue to increase funding for higher education and research over time, to merge small universities and independent research institutes to build strong research universities, and to allow underperforming institutions that do not improve over time to shut down.

- Move towards multi-year budgets for universities. Induce universities to do more fundraising by offering matching grants.

- $\quad$ Ensure that allocation criteria for financing are based on research quality and impact.

- Improve the quality of doctoral training by structuring it through coursework and tutoring and tightening entry criteria.

- Offer well-remunerated academic positions, and base career progression on an evaluation of research and teaching quality by faculty and external experts. Adjust the timing of evaluations to allow for family-related career breaks.

- Engage with the research diaspora, and develop systematic policies to attract researchers from abroad and send Polish researchers and students to foreign countries.

- Develop a strategy for modern entrepreneurship training as part of the envisaged higher education reform.

- Ensure sufficient funding for technology transfer offices, and encourage mergers of offices from different universities.

- Take technology transfer out of the realm of public finance.

Education and training

- Develop a national skills strategy with a strong basic skills component.

- Incentivise employers to develop workplace-based vocational education and adult training.

- Dedicate multi-annual financing to build strong workplace-based vocational education programmes cofinanced and -managed with business.

- $\quad$ Attract highly qualified teachers to sectoral schools through attractive pay and career prospects. Strengthen basic-skills training, and adjust subject content in Polish and maths to pupils' practical training context.

- Evaluate and expand the new system to certify training providers and the public database detailing their quality and courses. Ensure that training quality control is sufficiently staffed.

Innovation support

- Continue the simplification of administrative procedures and tax laws without foregoing rules that are essential to ensure good environmental, social and economic outcomes.

- Continue simplifying procedures to apply for EU funds. Allow more for personal presentation of projects, while directing promising candidates to coaching to develop and apply their ideas, if needed.

- Develop brokerage and consulting services to help SMEs make better use of innovation support and technology.

- $\quad$ Provide for systematic evaluation of the economic effects of innovation support. Set aside funding for that, including for evaluation based on experimental methods.

- Provide regions with central government support to improve their public procurement capacity. Ease application procedures for EU funds that they administer.

- $\quad$ Concentrate support for clusters and technology parks on improving their management, such as support for members to expand abroad, network and obtain training. 


\section{BIBLIOGRAPHY}

Abramovsky, L., R. Harrison and H. Simpson (2007), "University research and the location of business R\&D”, Economic Journal, Vol. 117, pp. C114-C141.

Aw, B., M. Roberts and T. Winston (2007), "Export market participation, investments in R\&D and worker training, and the evolution of firm productivity", World Economy, Vol. 30, pp. 83-104.

Belderbos, R., V. van Roy, B. Leten, B and B. Thijs, B (2014), “Academic research strengths and multinational firms' foreign R\&D location decisions: Evidence from R\&D investments in European regions", Environment and Planning, Vol. 46, pp. 920-42.

Bundesinstitut für berufliche Bildung (BIBB) (2015), Kosten und Nutzen der betrieblichen Ausbildung, Bonn.

Boermans, M. and H. Roelfsema (2015), "The effects of internationalization on innovation: Firm-level evidence for transition economies", Open Economies Review, Vol. 26, pp. 333-50.

Burger, M., B. Karreman, and F. van Eenennaam (2015), "The competitive advantage of clusters: Cluster organisations and greenfield FDI in the European life sciences industry", Geoforum, Vol. 65, pp. $179-91$.

Carlino, G. and W. R. Kerr (2015), "Error! Hyperlink reference not valid.” in G. Duranton, J.V. Henderson and W.C. Strange (eds.), Handbook of Regional and Urban Economics, Vol. 5, Elsevier, Amsterdam, Chap. 6, pp. 349-404.

Cieślik, A. (2005), "Regional characteristics and the location of foreign firms within Poland", Applied Economics, Vol. 37, pp. 863-74.

Chatterji, A., E. Glaeser, E. and W. Kerr (2014). "Clusters of entrepreneurship and innovation.” in J. Lerner and S. Stern (eds.), Innovation Policy and the Economy, Vol. 14, University of Chicago Press, Chicago.

Cizkowicz, P., M. Cizkowicz-Pelaka, P. Pekala and A. Rzonca (2015), "The effects of special economic zones on employment and investment: Spatial panel modelling perspective", Narodowy Bank Polski Working Paper, No. 208, Warsaw.

Dubois, P., J. Rochet, and J. Schlenker (2014), "Productivity and mobility in academic research: Evidence from mathematicians", Scientometrics, Vol. 98, pp. 1669-1701.

Engel, D., T. Mitz, R. Patuelli, and J. Reinkowski (2013), "Does cluster policy trigger R\&D activity? Evidence from German biotech contests", European Planning Studies, Vol. 21, pp. 1735-59.

European Commission (2017), Poland's Higher Education and Science System - Horizon 2020 Peer Review, Brussels.

Falck, O., S. Kipar and S. Heblich (2010), "Industrial innovation: Direct evidence from a cluster-oriented policy”, Regional Science and Urban Economics, Vol. 40, pp. 574-82.

Foray, D. (2013), "The economic fundamentals of smart specialisation”, Ekonomiaz, Vol. 83, pp. 83-102. 
Gorodnichenko, Y., J. Svejnar, J. and K. Terrell (2014), "When does FDI have positive spillovers? Evidence from 17 transition market economies", Journal of Comparative Economics, Vol. 42, pp. 954-69.

Hagemejer, J. and M. Kolasa (2011), "Internationalisation and economic performance of enterprises: Evidence from Polish firm-level data", The World Economy, Vol. 34, pp. 74-100.

Hagemejer, J. and J. Tyrowicz (2012), "Is the effect really so large? Firm-level evidence on the role of FDI in a transition economy", Economics of Transition, Vol. 20, pp. 195-233.

Hausmann, R. and D. Rodrik (2003), "Economic development as self-discovery", Journal of Development Economics, Vol. 72, pp. 603-633.

Harding, T. and B. Javorcik (2013) "Investment Promotion and FDI Inflows: Quality Matters." CESifo Economic Studies, Vol. 59, pp. 337-59.

Harhoff, D. (1999), "Firm formation and regional spillovers-evidence from Germany", Economics of Innovation and New Technology, Vol. 8, pp. 27-55.

Jensen, C. and M. Winiarczyk (2014), “Special Economic Zones-20 years later”, CASE Research Paper,No. 467, Warsaw.

Kapil, N., M. Piatkowski, I. Radwan and J. Gutierrez, (2013), "Poland enterprise innovation support review: From catching up to moving ahead”, World Bank Working Paper, No. 75325, Washington.

Kolasa, M. (2008), "How does FDI inflow affect productivity of domestic firms? The role of horizontal and vertical spillovers, absorptive capacity and competition", The Journal of International Trade \& Economic Development, Vol. 17, pp. 155-73.

Klincewicz, K. and K. Szkuta (2015), RIO Country Report: Poland, Joint Research Centre, Sevilla.

Martin, P., T. Mayer and F. Mayneris (2011), "Public support to clusters: A firm level study of French, local productive systems”, Regional Science and Urban Economics, Vol. 41, pp. 108-23.

Narodowy Bank Polski (NBP) (2016), Potencjał innowacyjny gospodarki: Uwarunkowania, determinanty, perspektywy, Warsaw.

Najwyżsa Izba Kontroli (NIK) (2016), Działalność Ośrodków Innowacji, Warsaw.

Nishimura, J. and H. Okamuro (2011), "R\&D productivity and the organization of cluster policy: An empirical evaluation of the Industrial Cluster Project in Japan”, Journal of Technology Transfer, Vol. 36, pp. 117-44.

OECD (2010), Innovation Vouchers, OECD Publishing, Paris. http://www.oecd.org/innovation/policyplatform/48135973.pdf.

OECD (2011), Attractiveness for Innovation: Location Factors for International Investment, OECD Publishing, Paris. http://dx.doi.org/10.1787/9789264104815-en.

OECD (2016a), OECD Economic Surveys - Poland, OECD Publishing, Paris. 
OECD (2016b), OECD Public Governance Review - Public Procurement for Innovation, OECD Publishing, Paris.

OECD (2016c), Investing in Youth: Australia, OECD Publishing, Paris.

OECD (2017), HEInnovate Country Report - Universities, Entrepreneurship and Local Development Poland, OECD Publishing, Paris.

PARP (2015), The Study of Human Capital in Poland, Warsaw.

Siedschlag, J., D. Smith, D. Turcu and X. Zhang (2013)., "What determines the location choice of R\&D activities by multinational firms?”, Research Policy, Vol. 42, pp. 1420-30.

Rodríguez-Pose, A. and C. Wilkie (2016), "Context and the role of policies to attract foreign R\&D in Europe", European Planning Studies, Vol. 24, pp. 2014-35

Starzyńska, W. and A. Borowicz, (2012), "The pro-innovative effect of Poland's public procurement system on the country's economy", paper presented at the Demand, Innovation and Policy Underpinning Policy Trends with Academic Analysis conference, Manchester Institute of Innovation Research, MBS, University of Manchester, 22-23 March.

Urząd Zamówień Publicznych (UZP) (2015) "Sprawozdanie Prezesa Urzędu Zamówień Publicznych o funkcjonowaniu systemu zamówień publicznych w 2014 r.”, Warsaw. https://www.uzp.gov.pl/_data/assets/pdf_file/0021/21936/Sprawozdanie_Prezesa_Uzp_2014.pdf

Worek, B., K. Turek and A. Szczucka (2015), "Problemy i dylematy rozwoju polskiego systemu uczenia się przez całe życie”, Edukacja, pp. $151-67$. 